\title{
Summertime nitrate aerosol in the upper troposphere and lower stratosphere over the Tibetan Plateau and the South Asian summer monsoon region
}

\author{
Yixuan Gu ${ }^{1,2}$, Hong Liao ${ }^{3}$, and Jianchun Bian ${ }^{4}$ \\ ${ }^{1}$ State Key Laboratory of Atmospheric Boundary Layer Physics and Atmospheric Chemistry (LAPC), Institute of \\ Atmospheric Physics, Chinese Academy of Sciences, Beijing, China \\ ${ }^{2}$ University of Chinese Academy of Sciences, Beijing, China \\ ${ }^{3}$ School of Environmental Science and Engineering, Nanjing University of Information Science \& Technology, \\ Nanjing, China \\ ${ }^{4}$ Key Laboratory of Middle Atmosphere and Global Environment Observation (LAGEO), Institute of Atmospheric Physics, \\ Chinese Academy of Sciences, Beijing, China
}

Correspondence to: Hong Liao (hongliao@ nuist.edu.cn)

Received: 8 October 2015 - Published in Atmos. Chem. Phys. Discuss.: 13 November 2015

Revised: 8 May 2016 - Accepted: 15 May 2016 - Published: 2 June 2016

\begin{abstract}
We use the global three-dimensional Goddard Earth Observing System chemical transport model (GEOSChem) to examine the contribution of nitrate aerosol to aerosol concentrations in the upper troposphere and lower stratosphere (UTLS) over the Tibetan Plateau and the South Asian summer monsoon (TP/SASM) region during summertime of year 2005. Simulated surface-layer aerosol concentrations are compared with ground-based observations, and simulated aerosols in the UTLS are evaluated by using the Stratospheric Aerosol and Gas Experiment II satellite data. Simulations show elevated aerosol concentrations of sulfate, nitrate, ammonium, black carbon, organic carbon, and $\mathrm{PM}_{2.5}$ (particles with diameter equal to or less than $2.5 \mu \mathrm{m}$, defined as the sum of sulfate, nitrate, ammonium, black carbon, and organic carbon aerosols in this study) in the UTLS over the TP/SASM region throughout the summer. Nitrate aerosol is simulated to be of secondary importance near the surface but the most dominant aerosol species in the UTLS over the studied region. Averaged over summertime and over the TP/SASM region, $C_{\text {NIT }}$ (the ratio of nitrate concentration to $\mathrm{PM}_{2.5}$ concentration) values are $5-35 \%$ at the surface, $25-50 \%$ at $200 \mathrm{hPa}$, and could exceed $60 \%$ at $100 \mathrm{hPa}$. The mechanisms for the accumulation of nitrate in the UTLS over the TP/SASM region include vertical transport and the gasto-aerosol conversion of $\mathrm{HNO}_{3}$ to form nitrate. The high rel-
\end{abstract}

ative humidity and low temperature associated with the deep convection over the TP/SASM region are favorable for the gas-to-aerosol conversion of $\mathrm{HNO}_{3}$.

\section{Introduction}

Aerosols in the upper troposphere and lower stratosphere (UTLS) have much longer residence times than those in the lower troposphere, influencing atmospheric chemistry and the Earth's climate with large spatial and temporal coverage (Rasch et al., 2008). Aerosols in the UTLS influence the concentrations of chemical species via changes in photolysis rates and heterogeneous reactions (Pitari et al., 2014). For example, heterogeneous reactions on sulfate aerosol can perturb the chemical partitioning in the lower stratosphere, leading to significant $\mathrm{O}_{3}$ depletion through enhanced chlorine, bromine, and odd-hydrogen catalytic cycle (Zhao et al., 1997; Considine et al., 2001; Talukdar et al., 2012; Tang et al., 2014; Pitari et al., 2014). Aerosols in the UTLS also influence climate by altering properties of cirrus clouds via homogeneous or heterogeneous ice nucleation (Li et al., 2005; Liu et al., 2009; Yin et al., 2012; Fadnavis et al., 2013). Injection of aerosols into the UTLS has been reported to induce complex responses in circulation, temperature, and water vapor 
(Liu et al., 2009; Wu et al., 2011; Su et al., 2011; Fadnavis et al., 2013).

Aerosols over the Tibetan Plateau (TP) and the Asian summer monsoon region are especially important. The TP is surrounded by countries with large anthropogenic emissions ( $\mathrm{Li}$ et al., 2005; Lau et al., 2006). Aerosols from India, Southeast Asia, and southern China can be transported to the TP by prevailing winds in the pre-monsoon and monsoon seasons (Lawrence and Lelieveld, 2010; Xia et al., 2011). Observational and modeling studies have shown that persistent maxima of atmospheric constituents, such as water vapor (Gettelman et al., 2004; Randel and Park, 2006; Park et al., 2007), CO (Kar et al., 2004; Li et al., 2005; Park et al., 2007, 2008, 2009), $\mathrm{CH}_{4}$ (M. Park et al., 2004; Xiong et al., 2009), $\mathrm{NO}_{x}$ (M. Park et al., 2004), HCN (Park et al., 2008; Randel et al., 2010), $\mathrm{C}_{2} \mathrm{H}_{6}$ and $\mathrm{C}_{2} \mathrm{H}_{2}$ (Park et al., 2008), exist in the UTLS above the TP and the South Asian summer monsoon (SASM) region because of the deep convection during boreal summer. Satellite observations suggested that the convection associated with the SASM is a vital pathway to transport air mass from the lower troposphere into the stratosphere (Chen et al., 2006; Randel and Park, 2006; Randel et al., 2010; Bian et al., 2011a). The heating associated with the persistent deep convection during summertime leads to the formation of the Tibetan anticyclone in the UTLS, which acts to isolate air within the anticyclone and traps the uplifted pollutants at that altitude (Park et al., 2007; Vernier et al., 2011; Bourgeois et al., 2012; Fadnavis et al., 2013; He et al., 2014). The stratosphere-troposphere exchange (STE) over the TP contributes largely to the global STE (Chen et al., 2006).

Previous studies have reported that aerosols exist in the UTLS over the TP/SASM region. Kim et al. (2003) carried out optical measurements with a ground-based lidar in Lhasa from August to October of 1999, and found an enhancement in aerosol concentration near the local tropopause with scattering ratio (SR, the ratio of aerosol plus molecular backscatter to molecular backscatter alone) of 1.1-1.2. Tobo et al. (2007) reported an enhancement of submicron aerosols (effective radius $r=0.15-0.6 \mu \mathrm{m}$ ) near the summertime tropopause (about 130 to $70 \mathrm{hPa}$ ), on the basis of in situ balloon measurements from an Optical Particle Counter at the same location in August of 1999. Vernier et al. (2009) examined satellite measurements from the Cloud-Aerosol Lidar with Orthogonal Polarization (CALIOP) on board CloudAerosol Lidar and Infrared Pathfinder Satellite Observation (CALIPSO) and reported the presence of small depolarizing particles with high SR values (about 1.20 at $532 \mathrm{~nm}$ ) at $16-17 \mathrm{~km}$ altitude over South Asia in July and August of 2007 and 2008. Bourgeois et al. (2012) found that an aerosol layer existed at $16-18 \mathrm{~km}$ altitude over the Asian continent and Indian Ocean $\left(20^{\circ} \mathrm{S}-30^{\circ} \mathrm{N}, 5-105^{\circ} \mathrm{E}\right)$ on the basis of the CALIOP observations. Recently, He et al. (2014) examined the vertical profiles of aerosol extinction coefficients measured with a Micro Pulse Lidar at Naqu, a meteorological station located in the central part of the TP, and also showed a maximum in aerosol extinction coefficient $\left(\sim 2.10^{-3} \mathrm{~km}^{-1}\right)$ in the UTLS (18-19 km) during the summer of 2011.

A number of previous studies have attempted to understand the chemical composition of aerosols in the UTLS. Froyd et al. (2009) measured aerosol composition with the National Oceanic and Atmospheric Administration (NOAA) single-particle mass spectrometer aboard the National Aeronautics and Space Administration (NASA) WB-57 highaltitude aircraft platform, and reported that particles in the tropical tropopause layer were rich in nitrogen. Vernier et al. (2011) suggested that aerosol layer at the tropopause of Asia could be sulfur and/or organics, considering that Asian pollutants consisted of black carbon, organic carbon, $\mathrm{SO}_{2}$, and $\mathrm{NO}_{x}$ (Park et al., 2009; Randel et al., 2010). Weigel et al. (2011) analyzed the volatility of aerosols obtained from in situ airborne measurements and reported that about 75-90\% of the particles in the tropical tropopause layer were volatile, but this study did not give any detailed analyses of chemical composition of aerosols. Bourgeois et al. (2012) showed, by using the ECHAM5.5-HAM2 model, that sulfate, water, and organic carbon (OC) contributed, respectively, 53, 29, and $11 \%$ to aerosol extinction in the vicinity of the tropical tropopause layer. The ECHAM5.5-HAM2 model used by Bourgeois et al. (2012) simulated all major aerosol species in the atmosphere except for nitrate.

Few previous studies have examined nitrate aerosol in the UTLS, although nitrate is expected to be important for the following reasons. First, emissions of precursors of nitrate, such as $\mathrm{NO}_{x}$ and $\mathrm{NH}_{3}$, are high over India, Southeast Asia, and China (Streets et al., 2003; Datta et al., 2012; Huang et al., 2012). Second, simulated nitrate concentrations are high over those regions (Liao and Seinfeld, 2005; Mu and Liao, 2014; Lou et al., 2014). Third, measured concentrations of nitrate are comparable to or larger than those of sulfate at rural and urban sites in the SASM region. Shrestha et al. (2000) carried out measurements of aerosols at Phortse, Nepal, during September 1996-November 1997, and showed that the average concentration of nitrate during the monsoon season (June-September) was $0.34 \mu \mathrm{g} \mathrm{m}^{-3}$, higher than that of sulfate $\left(0.17 \mu \mathrm{g} \mathrm{m}^{-3}\right)$. Decesari et al. (2010) reported, on the basis of measurements at the Nepal Climate ObservatoryPyramid from 2006 to 2008, that the concentrations of nitrate and sulfate were 0.37 and $0.50 \mu \mathrm{g} \mathrm{m}^{-3}$, respectively, during the monsoon season. Chatterjee et al. (2010) measured aerosols at a high-altitude station in the northeastern Himalayas during January-December 2005. They found that the average concentrations of fine-mode nitrate and sulfate were $3.31 \pm 2.25$ and $3.80 \pm 2.9 \mu \mathrm{g} \mathrm{m}^{-3}$, respectively. At Lahore, an urban site in Pakistan, the observed daytime nitrate concentration of $21.8 \mu \mathrm{g} \mathrm{m}^{-3}$ was also higher than sulfate concentration of $12.6 \mathrm{~g} \mathrm{~m}^{-3}$ (Lodhi et al., 2009), as the observations were averaged over November 2005 to March 2006. Fourth, the low temperatures in the UTLS would favor nitrate formation (Seinfeld and Pandis, 2006). 
Therefore, it is of interest to take nitrate aerosol into consideration when we examine aerosols in the UTLS.

In this work we simulate nitrate aerosol and its contribution to aerosol concentrations in the UTLS over the TP (70$\left.105^{\circ} \mathrm{E}, 25-40^{\circ} \mathrm{N}\right)$ and the SASM region $\left(70-105^{\circ} \mathrm{E}, 10\right.$ $25^{\circ} \mathrm{N}$ ) by using the global Goddard Earth Observing System chemical transport model (GEOS-Chem) driven by the assimilated meteorological fields. These regions of interest are shown in Fig. 1. Simulated surface-layer aerosol concentrations are compared with ground-based observations, and simulated aerosols in the UTLS are evaluated by using the Stratospheric Aerosol and Gas Experiment II (SAGE II) satellite data. Section 2 is a brief description of the GEOSChem model and numerical experiment. Section 3 presents the simulation and evaluation of distributions and concentrations of $\mathrm{HNO}_{3}$ and $\mathrm{O}_{3}$ to show the model's capability in simulating the $\mathrm{NO}_{x}-\mathrm{O}_{3}-\mathrm{HNO}_{3}$ cycle over the studied regions. Section 4 shows simulated aerosols and Sect. 5 presents the simulated contribution of nitrate to aerosol concentrations in the UTLS over the TP and the SASM region. Section 6 discusses the mechanisms for high concentrations of nitrate in the UTLS. Section 7 discusses the impacts of uncertainties in surface-layer aerosol concentrations on simulated nitrate in the UTLS.

\section{Model description and numerical experiment}

\subsection{GEOS-Chem model}

We simulate gas-phase species and aerosols using the global chemical transport model GEOS-Chem (version 9-01-03, http://geos-chem.org) driven by the GEOS-5 assimilated meteorological fields from the Goddard Earth Observing System of the NASA Global Modeling and Assimilation Office. The version of the model used here has a horizontal resolution of $2^{\circ}$ latitude by $2.5^{\circ}$ longitude and 47 vertical layers extending from the surface to $0.01 \mathrm{hPa}$. Over the TP and the SASM region, the model has about 34 layers in the troposphere and 12 layers in the stratosphere.

The GEOS-Chem model has a fully coupled treatment of tropospheric $\mathrm{NO}_{x}-\mathrm{CO}$-hydrocarbon-aerosol chemistry and aerosols including sulfate $\left(\mathrm{SO}_{4}^{2-}\right)$, nitrate $\left(\mathrm{NO}_{3}^{-}\right)$, ammonium $\left(\mathrm{NH}_{4}^{+}\right)$, organic carbon (OC), black carbon (BC) (R. J. Park et al., 2003, 2004; Pye et al., 2009), mineral dust (Fairlie et al., 2007), and sea salt (Alexander et al., 2005; Jaeglé et al., 2011). Anthropogenic aerosols are treated as bulk mass concentrations (particles of $\mathrm{SO}_{4}^{2-}, \mathrm{NO}_{3}^{-}, \mathrm{NH}_{4}^{+}$, $\mathrm{BC}$, and $\mathrm{OC}$ are not size-resolved). Sea salt mass is simulated for two size bins $(0.1-0.5$ and $0.5-8 \mu \mathrm{m})$ and mineral dust is simulated for four size bins $(0.1-1.0,1.0-1.8,1.8-3.0$, and 3.0-6.0 $\mu \mathrm{m}$ ). Both BC and OC consist of hydrophilic and hydrophobic fractions in the model. It is assumed that $80 \%$ of $\mathrm{BC}$ and $50 \%$ of OC emitted from all primary sources are hydrophobic (Cooke et al., 1999; Chin et al., 2002; Chung

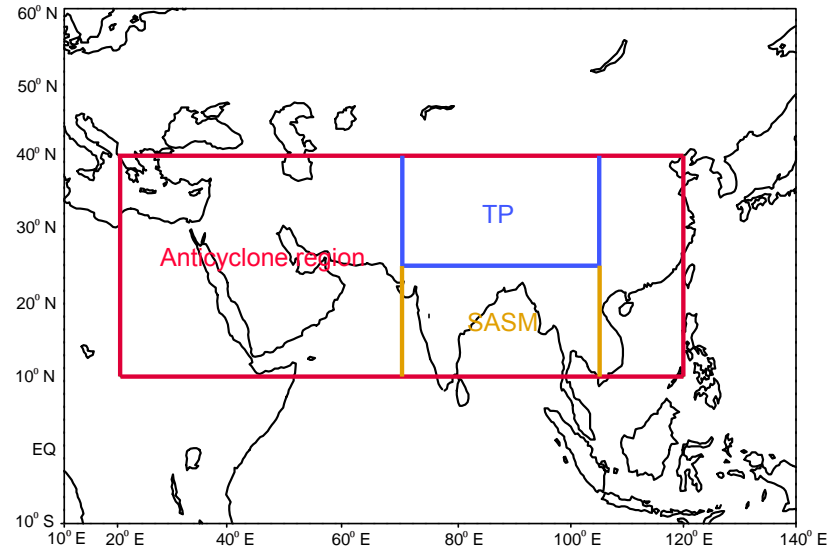

Figure 1. Regions examined in this study: the Tibetan Plateau region $\left(\mathrm{TP}, 70-105^{\circ} \mathrm{E}, 25-40^{\circ} \mathrm{N}\right.$ ), the SASM region (SASM, 70$\left.105^{\circ} \mathrm{E}, 10-25^{\circ} \mathrm{N}\right)$, and the anticyclone region of $\left(20-120^{\circ} \mathrm{E}, 10\right.$ $\left.40^{\circ} \mathrm{N}\right)$.

and Seinfeld, 2002), which become hydrophilic with an efolding time of 1.2 days following Cooke et al. (1999) and Chin et al. (2002). All secondary OC is assumed to be hydrophilic. Hydrophilic fractions of both $\mathrm{BC}$ and $\mathrm{OC}$ aerosols are assumed to be fully soluble.

The gas-aerosol partitioning of nitric acid and ammonium is calculated using the ISORROPIA II thermodynamic equilibrium module (Fountoukis and Nenes, 2007). In the version of the GEOS-Chem model used in this work, ions considered in ISORROPIA II include $\mathrm{H}^{+} / \mathrm{Na}^{+} / \mathrm{NH}_{4}^{+} / \mathrm{Cl}^{-} / \mathrm{SO}_{4}^{2-} / \mathrm{HSO}_{4}^{-} / \mathrm{NO}_{3}^{-} / \mathrm{OH}^{-}$. The two-way coupling between aerosols and gas-phase chemistry provides consistent chemical fields for aerosol simulation and aerosol mass for heterogeneous processes and calculations of gasphase photolysis rates. Heterogeneous reactions include hydrolysis of $\mathrm{N}_{2} \mathrm{O}_{5}$ (Evans and Jacob, 2005), irreversible absorption of $\mathrm{NO}_{3}$ and $\mathrm{NO}_{2}$ on wet aerosols (Jacob, 2000), and the uptake of $\mathrm{HO}_{2}$ by aerosols (Liao and Seinfeld, 2005; Thornton et al., 2008). Aerosol species are treated as an external mixture in the calculation of aerosol optical properties.

With respect to chemistry in the stratosphere, stratospheric $\mathrm{O}_{3}$ concentrations are calculated using the linearized parameterization scheme (McLinden et al., 2000). The monthly mean production rates and loss frequencies of other stratospheric species (including long-lived species such as CFCs and $\mathrm{N}_{2} \mathrm{O}$ ) use those from NASA Global Modeling Initiative (GMI) Combo simulations (Considine et al., 2008; Murray et al., 2012).

Convective transport in GEOS-Chem mimics that in the parent GEOS general circulation model (Hack, 1994; Zhang and McFarlane, 1995), which accounts for updraft, downdraft, and entrainment mass fluxes for deep and shallow convection (Wu et al., 2007). The aerosol wet deposition scheme in the GEOS-Chem follows that of Liu et al. (2001). For the scavenging of aerosols, $\mathrm{SO}_{4}^{2-}, \mathrm{NO}_{3}^{-}, \mathrm{NH}_{4}^{+}$, and hydrophilic 
Table 1. Summary of annual emissions of aerosols and aerosol precursors in Asia $\left(60-155^{\circ} \mathrm{E}, 10-55^{\circ} \mathrm{N}\right)$.

\begin{tabular}{|c|c|c|}
\hline Species & Global & Asia \\
\hline \multicolumn{3}{|c|}{$\mathrm{NO}_{x}\left(\mathrm{Tg} \mathrm{N}_{\mathrm{yr}}{ }^{-1}\right)$} \\
\hline Aircraft & 0.5 & 0.08 \\
\hline Anthropogenic & 28.6 & 9.96 \\
\hline Biomass burning & 4.7 & 0.27 \\
\hline Fertilizer & 0.7 & 0.31 \\
\hline Lightning & 5.9 & 0.87 \\
\hline Soil & 5.9 & 0.96 \\
\hline Total & 46.3 & 12.45 \\
\hline \multicolumn{3}{|c|}{$\mathrm{SO}_{2}\left(\mathrm{Tg} \mathrm{S} \mathrm{yr}^{-1}\right)$} \\
\hline Aircraft & 0.1 & 0.01 \\
\hline Anthropogenic & 52.6 & 23.46 \\
\hline Biomass burning & 1.2 & 0.07 \\
\hline Volcanoes & 4.4 & 1.04 \\
\hline No_eruption & 8.9 & 1.78 \\
\hline Ship & 7.4 & 0.94 \\
\hline Total & 74.6 & 27.30 \\
\hline \multicolumn{3}{|c|}{$\mathrm{NH}_{3}\left(\mathrm{Tg} \mathrm{N} \mathrm{yr}^{-1}\right)$} \\
\hline Anthropogenic & 34.9 & 17.83 \\
\hline Natural & 14.2 & 2.01 \\
\hline Biomass burning & 3.5 & 0.21 \\
\hline Biofuel & 1.6 & 0.71 \\
\hline Total & 54.2 & 20.76 \\
\hline \multicolumn{3}{|c|}{$\mathrm{OC}(\mathrm{Tg} \mathrm{C} \mathrm{yr}-1)$} \\
\hline Anthropogenic & 3.1 & 1.42 \\
\hline Biomass burning & 18.7 & 1.10 \\
\hline Biofuel & 6.3 & 3.28 \\
\hline Biogenic & 9.7 & 1.22 \\
\hline Total & 37.8 & 7.02 \\
\hline \multicolumn{3}{|c|}{$\mathrm{BC}\left(\mathrm{Tg} \mathrm{C} \mathrm{yr}^{-1}\right)$} \\
\hline Anthropogenic & 3.0 & 1.43 \\
\hline Biomass burning & 2.2 & 0.12 \\
\hline Biofuel & 1.6 & 0.86 \\
\hline Total & 6.8 & 2.41 \\
\hline
\end{tabular}

OC and hydrophilic BC aerosols are assumed to be fully soluble. Dry deposition follows the standard resistance-in-series model of Wesely (1989).

Global emissions of aerosols and their precursors in the GEOS-Chem follow R. J. Park et al. (2003, 2004), with anthropogenic emissions of $\mathrm{NO}_{x}, \mathrm{CO}, \mathrm{SO}_{2}$, and non-methane volatile organic compounds in Asia overwritten by David Streets' 2006 emission inventory (http://mic.greenresource. $\mathrm{cn} /$ intex-b2006). Emissions of $\mathrm{NH}_{3}$ in Asia are taken from Streets et al. (2003). Since $\mathrm{NH}_{3}$ emissions in China showed large uncertainties in previous studies (Streets et al., 2003; Kim et al., 2006; Y. Zhang et al., 2010; Huang et al., 2011, 2012), we use the most recent estimate of $\mathrm{NH}_{3}$ emissions in

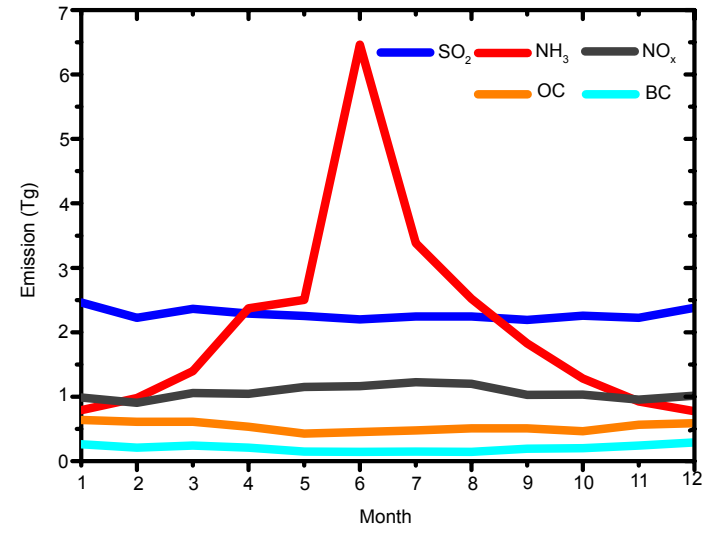

Figure 2. Monthly variations in emissions of $\mathrm{NO}_{x}\left(\mathrm{Tg} \mathrm{N}_{\text {month }}{ }^{-1}\right)$,

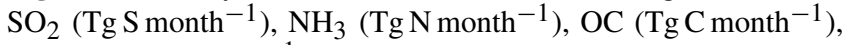
and $\mathrm{BC}\left(\mathrm{TgC}\right.$ month $^{-1}$ ) over Asia. Values shown are the total emissions (anthropogenic plus natural emissions listed in Table 1).

China by Huang et al. (2012), which is $9.8 \mathrm{Tg} \mathrm{yr}^{-1}$, instead of $13.5 \mathrm{Tg} \mathrm{yr}^{-1}$ from Streets et al. (2003). Table 1 summarizes the annual emissions of $\mathrm{NO}_{x}, \mathrm{SO}_{2}, \mathrm{NH}_{3}, \mathrm{OC}$, and $\mathrm{BC}$ in the Asia domain $\left(60-155^{\circ} \mathrm{E}, 10-55^{\circ} \mathrm{N}\right)$.

Natural $\mathrm{NO}_{x}$ emissions from lightning are calculated using the scheme described by Sauvage et al. (2007) and Murray et al. (2012), and those from soil are simulated following Wang et al. (1998). Natural $\mathrm{NH}_{3}$ emissions from soil, vegetation, and the oceans are taken from the Global Emissions Inventory Activity inventory (Bouwman et al., 1997). Biomass burning emissions are from the monthly Global Fire Emissions Database (GFED v3) driven by satellite observations of fire activity (van der Werf et al., 2010). Biogenic volatile organic compounds emissions are calculated from the Model of Emissions of Gases and Aerosols from Nature (Guenther et al., 2006).

The monthly variations of emissions of $\mathrm{SO}_{2}$ and $\mathrm{NO}_{x}$ follow Wang et al. (2013) and those of BC and OC follow Lou et al. (2014). The monthly scaling factors for $\mathrm{NH}_{3}$ emissions follow the global inventory described in Fisher et al. (2011). Monthly variations of emissions (anthropogenic plus natural emissions) of $\mathrm{NO}_{x} \mathrm{SO}_{2}, \mathrm{NH}_{3}, \mathrm{OC}$, and $\mathrm{BC}$ over Asia are displayed in Fig. 2. The emissions of $\mathrm{NH}_{3}$ are the highest in June as a result of the agriculture practice and high temperatures (Wang et al., 2013).

\subsection{Numerical experiment}

To examine the contribution of nitrate to aerosol concentrations in the UTLS over the TP/SASM region, we simulate aerosol concentrations by using the emissions of and meteorological fields of year 2005. Year 2005 is chosen so that we can use the observational data sets for this year from SAGE II and MLS (Microwave Limb Sounder), as described in Sects. 3 and 4. Following Rasch et al. (2008), we perform a 10-year spin-up run to generate the initial conditions (to al- 
low the stratospheric species to reach quasi-steady-state conditions). We would consider that the tropospheric simulation can be representative of year 2005 but stratosphere simulation should represent a multi-year average, because the production rates and loss frequencies in the stratosphere are the averages over years of 2004-2010 (http://wiki.seas.harvard. edu/geos-chem/index.php/Stratospheric_chemistry).

\section{Simulated concentrations of $\mathrm{HNO}_{3}$ and $\mathrm{O}_{3}$ and model evaluation}

Nitrate aerosol forms when nitric acid $\left(\mathrm{HNO}_{3}\right)$ reacts with alkaline gases (for example, ammonia) in the atmosphere (Seinfeld and Pandis, 2006). $\mathrm{HNO}_{3}$, as the important precursor of nitrate, is the major oxidation product of nitrogen oxides $\left(\mathrm{NO}_{x}=\mathrm{NO}+\mathrm{NO}_{2}\right)$ (Seinfeld and Pandis, 2006). To show the model's capability in simulating the $\mathrm{NO}_{x}-\mathrm{O}_{3}-\mathrm{HNO}_{3}$ cycle over the studied regions, we present and evaluate the simulated $\mathrm{HNO}_{3}$ and $\mathrm{O}_{3}$ in this section.

Simulated mixing ratios of $\mathrm{HNO}_{3}$ and $\mathrm{O}_{3}$ in the UTLS are evaluated by using data sets from the limb viewing satellite instrument of Microwave Limb Sounder (MLS, version 3.3, level 2, ftp://acdisc.gsfc.nasa.gov/data/s4pa///Aura MLS_Level2/). The MLS data sets provide valuable information on atmospheric compositions in the UTLS (Waters et al., 2006). For $\mathrm{HNO}_{3}$, the MLS provides scientifically useful data sets for 215 to $1.5 \mathrm{hPa}$, with a vertical resolution of 3-4 km and a horizontal resolution of $400-500 \mathrm{~km}$. Since further evaluations are needed for data sets at altitudes with pressures higher than $215 \mathrm{hPa}$ (Livesey et al., 2011), we use only data sets for pressures lower than that. For $\mathrm{O}_{3}$, the MLS provides scientifically useful data sets for 261 to $0.02 \mathrm{hPa}$, with a vertical resolution of $2.5-3 \mathrm{~km}$ and a horizontal resolution of $300-400 \mathrm{~km}$ in the UTLS (Santee et al., 2007; Livesey et al., 2011). The uncertainties of the MLS $\mathrm{HNO}_{3}$ and $\mathrm{O}_{3}$ data sets in the UTLS are discussed in Livesey et al. (2011).The MLS data $\mathrm{HNO}_{3}$ product at $100 \mathrm{hPa}$ represents an average of a 3-4 km layer reaching from below the tropopause layer into the lower stratosphere (Duncan et al., 2007). The data screening is conducted strictly according to the instructions of Livesey et al. (2011). For comparison with the MLS observations, the simulated $\mathrm{HNO}_{3}$ and $\mathrm{O}_{3}$ mixing ratios are converted to $\hat{x}$, following the method of Livesey et al. (2011):

$\hat{x}=x_{a}+\mathbf{A}\left(x-x_{a}\right)$,

where $\mathbf{A}$ is the averaging kernel matrix of the MLS, $x$ is the modeled vertical profile of $\mathrm{HNO}_{3}$ or $\mathrm{O}_{3}$ interpolated at the vertical grid of MLS, and $x_{a}$ is the $\mathrm{HNO}_{3}$ or $\mathrm{O}_{3}$ prior profile of MLS.

\section{$3.1 \mathrm{HNO}_{3}$}

Figure 3a shows the simulated global distribution of $\mathrm{HNO}_{3}$ concentrations averaged over June-August of 2005. Concen-

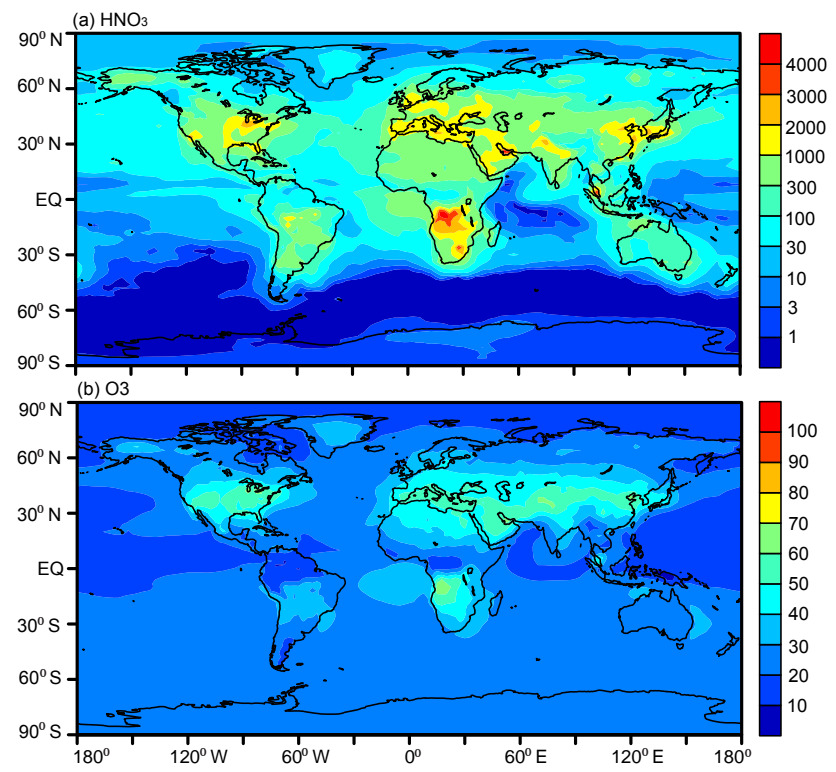

Figure 3. Simulated global distributions of surface-layer $\mathrm{HNO}_{3}$ (pptv) and $\mathrm{O}_{3}$ (ppbv) averaged over June-August 2005.

trations of $\mathrm{HNO}_{3}$ exceed $1 \mathrm{ppbv}$ over the industrialized areas such as Europe, North America, central and eastern Asia, and over biomass burning regions in the tropics, in agreement with the distributions and magnitudes reported in Liao et al. (2003). Over South Asia, simulated $\mathrm{HNO}_{3}$ concentrations are high $(0.3-1 \mathrm{ppbv})$ in the northern Indian subcontinent, because the emissions of $\mathrm{NO}_{x}$ and $\mathrm{NH}_{3}$ are high in this region (Streets et al., 2003; Zhang et al., 2009; Datta et al., 2012).

Figure $4 \mathrm{a}$ and $\mathrm{b}$ show the simulated $\mathrm{HNO}_{3}$ concentrations in the UTLS averaged over June-August of 2005. Since the tropopause is located at $70-150 \mathrm{hPa}(12-15 \mathrm{~km})$ over the TP/SASM region (Li et al., 2005; Bian et al., 2011b; Fadnavis et al., 2015), we choose the vertical layers of 200 and $100 \mathrm{hPa}$ to represent the UTLS. At both 200 and $100 \mathrm{hPa}$, the highest $\mathrm{HNO}_{3}$ concentrations are simulated to occur in the high-latitude regions in the Northern Hemisphere $(\mathrm{NH})$ (Fig. 4a and b). Simulated $\mathrm{HNO}_{3}$ concentrations at $100 \mathrm{hPa}$ are low over the region of $40-100^{\circ} \mathrm{E}$ and $10-30^{\circ} \mathrm{N}$, which is part of the anticyclone region defined in Fig. 1. Figure 4c shows the latitude-altitude cross section of simulated seasonal mean $\mathrm{HNO}_{3}$ mixing ratios averaged over $70-105^{\circ} \mathrm{E}$. In boreal summer, the highest $\mathrm{HNO}_{3}$ mixing ratios are simulated to occur at $30 \mathrm{hPa}$ over the polar regions in both hemispheres. Over high latitudes, $\mathrm{HNO}_{3}$ concentrations in the Southern Hemisphere (SH) are simulated to be higher than those in the NH.

To evaluate the simulated $\mathrm{HNO}_{3}$, Fig. $4 \mathrm{~d}-\mathrm{f}$ show $\mathrm{HNO}_{3}$ concentrations in the UTLS from MLS that are averaged over June-August of 2005 . At 200 and $100 \mathrm{hPa}$ altitudes, the observed $\mathrm{HNO}_{3}$ mixing ratios are high in the high latitudes in 

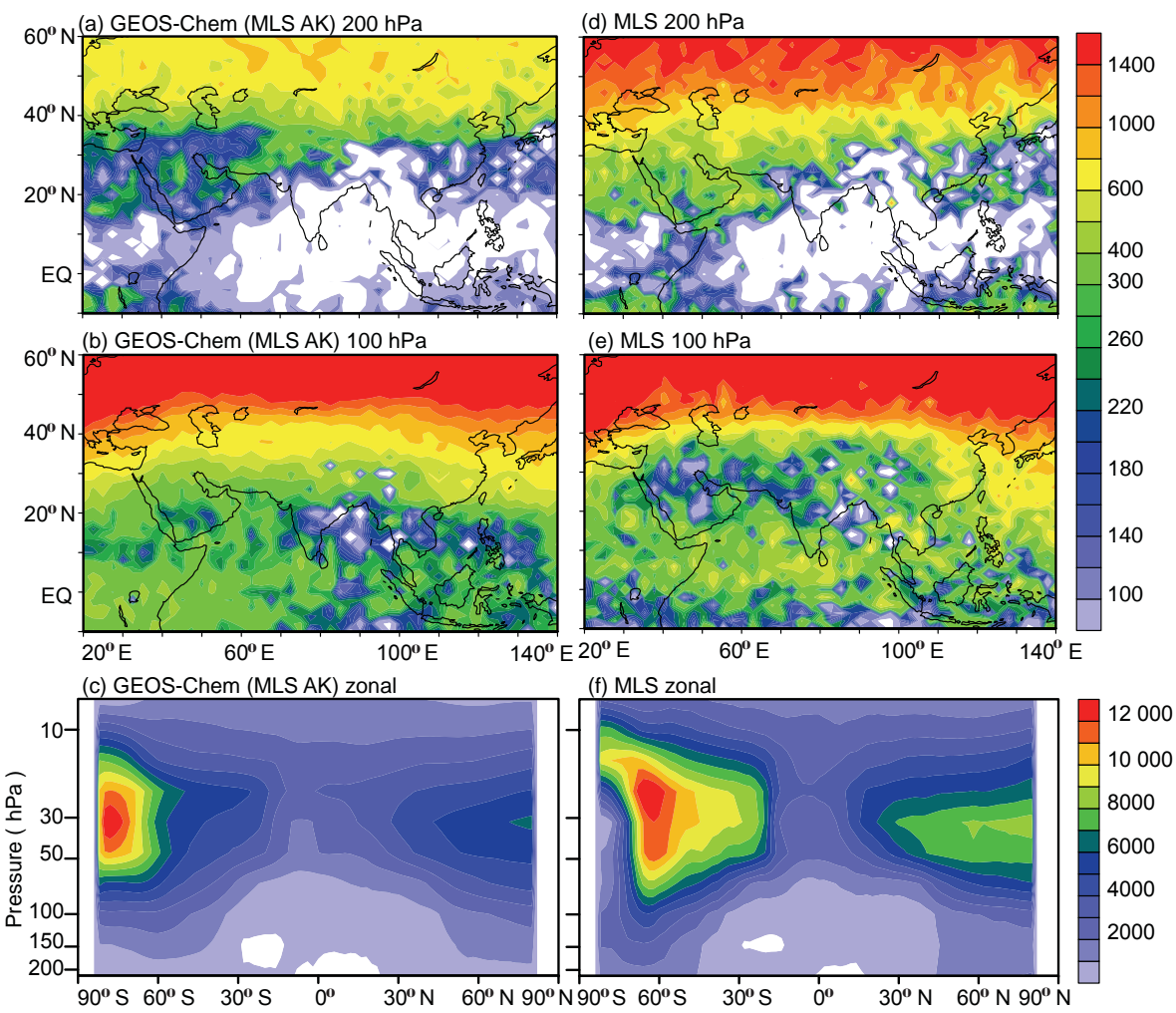

Figure 4. Comparisons of simulated $\mathrm{HNO}_{3}$ concentrations (pptv) with observations (pptv) from MLS. Panels (a) and (b) show simulated concentrations at 200 and $100 \mathrm{hPa}$, respectively. Panel (c) shows the latitude-altitude cross section of simulated $\mathrm{HNO}_{3}$ concentrations averaged over $70-105^{\circ}$ E. Panels (d)-(f) are the same as (a)-(c), except that (d)-(f) show observations from MLS. The GEOS-Chem HNO 3 simulations are smoothed by the corresponding averaging kernels (AKs). White areas indicate lack of data meeting the retrieval quality criteria. All the data are averaged over June-August of 2005.

the NH, which are captured by the GEOS-Chem model. The observed $\mathrm{HNO}_{3}$ at $100 \mathrm{hPa}$ exhibits low values of less than 400 pptv over $30-100^{\circ} \mathrm{E}$ and $10-30^{\circ} \mathrm{N}$ in the Asian monsoon anticyclone region (Fig. 4e). At $100 \mathrm{hPa}$, the observed $\mathrm{HNO}_{3}$ mixing ratio averaged over the TP/SASM region (70$105^{\circ} \mathrm{E}, 10-40^{\circ} \mathrm{N}$ ) is $335.4 \mathrm{pptv}$, which is lower than the simulated value of $372.6 \mathrm{pptv}$. Considering all the grid cells with $\mathrm{MLS} \mathrm{HNO}_{3}$ data available, the simulated seasonal mean $\mathrm{HNO}_{3}$ concentrations show normalized mean bias (NMB) of $+11.1 \%$ at $100 \mathrm{hPa}$ over the TP/SASM region in summer of year 2005. The observed pattern of the $\mathrm{HNO}_{3}$ vertical distribution (Fig. 4f) is also captured by the GEOS-Chem model (Fig. 4c). The distributions of $\mathrm{HNO}_{3}$ in the UTLS are associated with the Brewer-Dobson circulation proposed by Brewer (1949) and Dobson (1956), traveling upwards across the tropopause to the stratosphere at the equator and downwards to the troposphere near the polar region.

\section{$\begin{array}{ll}3.2 & \mathrm{O}_{3}\end{array}$}

Figure $3 \mathrm{~b}$ shows the global distribution of simulated summertime surface-layer $\mathrm{O}_{3}$ concentrations. Simulated $\mathrm{O}_{3}$ concentrations are in a range of 40-70 ppbv over Europe, North
America, China, and the biomass burning region of South Africa. Our model results agree closely with the simulated distributions and magnitudes reported in Mickley et al. (1999), Collins et al. (2000), Liao et al. (2003), Wu et al. (2008), Zeng et al. (2008), and Fadnavis et al. (2015). Fadnavis et al. (2015) also presented aircraft measurements over India in September of 2010 during the Cloud Aerosol Interaction and Precipitation Enhancement Experiment (CAIPEEX). Our simulated $\mathrm{O}_{3}$ concentrations of $30-$ 40 ppbv over India agree with the CAIPEEX measurements.

Figure $5 \mathrm{a}$ and $\mathrm{b}$ show the simulated $\mathrm{O}_{3}$ concentrations in the UTLS averaged over June-August of 2005. The distributions of $\mathrm{O}_{3}$ concentrations in the UTLS are similar to those of $\mathrm{HNO}_{3}$, with elevated values in the high latitudes of the $\mathrm{NH}$. Relatively low $\mathrm{O}_{3}$ mixing ratios of less than $200 \mathrm{ppbv}$ are simulated at $100 \mathrm{hPa}$ over $10-30^{\circ} \mathrm{N}, 20-110^{\circ} \mathrm{E}$, within the anticyclone region defined in Fig. 1. Our simulated distributions and magnitudes of $\mathrm{O}_{3}$ agree with those reported in Bian et al. (2011b), which examined the summertime distributions of $\mathrm{O}_{3}$ in the UTLS during 2005-2009 by using the MLS version 2.2 level 2 products (Livesey et al., 2008). Because the background $\mathrm{O}_{3}$ concentrations are generally high in the UTLS and the stratosphere, the low $\mathrm{O}_{3}$ concentrations 

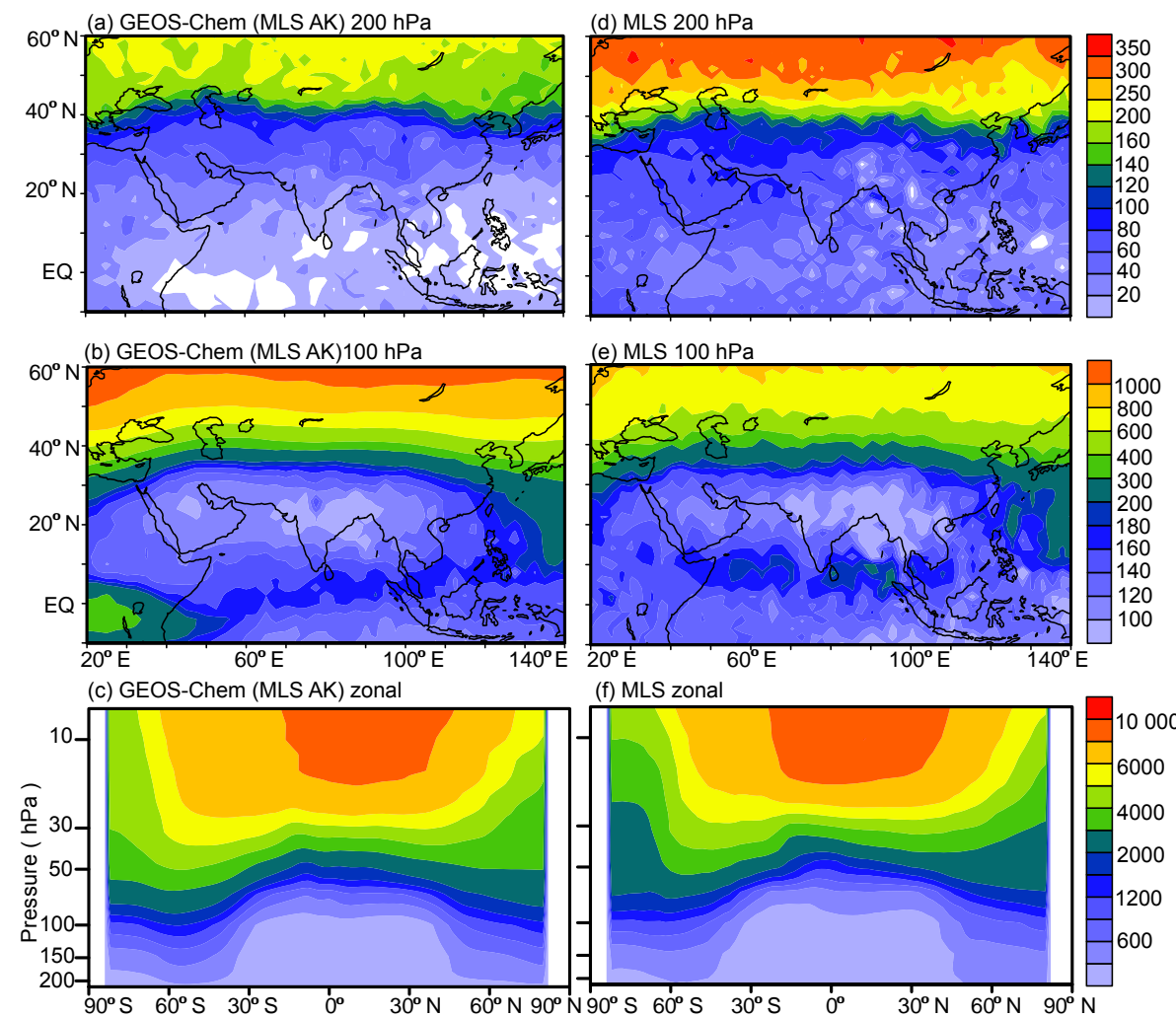

Figure 5. Comparisons of simulated $\mathrm{O}_{3}$ concentrations (ppbv) with observations (ppbv) from MLS. Panels (a) and (b) show simulated concentrations at 200 and $100 \mathrm{hPa}$, respectively. Panel (c) shows the latitude-altitude cross section of simulated $\mathrm{O}_{3}$ concentrations averaged over $70-105^{\circ}$ E. Panels (d)-(f) are the same as (a)-(c), except that (d)-(f) show observations from MLS. The GEOS-Chem $\mathrm{O}_{3}$ simulations are smoothed by the corresponding averaging kernels. White areas indicate lack of data meeting the retrieval quality criteria. All the data are averaged over June-August of 2005.

in the UTLS over the TP/SASM region are caused by the deep convection that transports $\mathrm{O}_{3}$-poor air upward (Fu et al., 2006; Randel and Park, 2006; Park et al., 2007; Bian et al., 2011b). Figure 5c displays the latitude-altitude cross section of seasonal mean $\mathrm{O}_{3}$ mixing ratios averaged over $70-105^{\circ} \mathrm{E}$. As a result of the Brewer-Dobson circulation, $\mathrm{O}_{3}$ concentrations in the UTLS are lower over the tropics than in the polar regions, even though the maximum $\mathrm{O}_{3}$ concentrations are located around $10 \mathrm{hPa}$ over the tropics (Brewer, 1949). Our simulated $\mathrm{O}_{3}$ concentrations in the UTLS agree well with the measurements from MLS (Fig. 5d-f). At $100 \mathrm{hPa}$, simulated and MLS observed $\mathrm{O}_{3}$ mixing ratios averaged over the TP/SASM region $\left(70-105^{\circ} \mathrm{E}, 10-40^{\circ} \mathrm{N}\right)$ are 151.7 and $146.6 \mathrm{ppbv}$, respectively. Compared to MLS observations, simulated $\mathrm{O}_{3}$ concentrations at $100 \mathrm{hPa}$ have a NMB of $+3.5 \%$ over the TP/SASM region in summer of 2005. Our simulated global STE of $\mathrm{O}_{3}$ is $420 \mathrm{Tg} \mathrm{yr}^{-1}$, which is within the range reported in previous studies $\left(475 \pm 120 \mathrm{Tg} \mathrm{yr}^{-1}\right.$ in McLinden et al., 2000, $420 \mathrm{Tg} \mathrm{yr}^{-1}$ in Škerlak et al., 2014, and $556 \pm 154 \mathrm{Tg} \mathrm{yr}^{-1}$ in Stevenson et al., 2006).

In addition to the comparisons against MLS products, the simulated $\mathrm{O}_{3}$ profiles are compared with balloon-borne sonde measurements in Fig. 6. The measurements were carried out at Kunming $\left(\mathrm{KM}, 102.7^{\circ} \mathrm{E}, 25.0^{\circ} \mathrm{N}\right)$ in August of 2009 and 2012, and at Lhasa $\left(\mathrm{LH}, 91.1^{\circ} \mathrm{E}, 29.7^{\circ} \mathrm{N}\right)$ in August of 2010 and 2013. The uncertainties of the observed $\mathrm{O}_{3}$ mixing ratios were estimated to be within 5-10\% (Bian et al., 2012). The comparisons with multi-year observations show that the model can reproduce the vertical distributions of $\mathrm{O}_{3}$ above $12 \mathrm{~km}$ in Kunming and Lhasa. At $100 \mathrm{hPa}$, the simulated monthly mean $\mathrm{O}_{3}$ mixing ratio in $\mathrm{KM}$ is $112.6 \mathrm{ppbv}$, and the observed value is $124.2 \mathrm{ppbv}$ in 2009 and $113.5 \mathrm{ppbv}$ in 2012. In $\mathrm{LH}$, the simulated monthly $\mathrm{O}_{3}$ mixing ratio at $100 \mathrm{hPa}$ is $152.6 \mathrm{ppbv}$, and the observed $\mathrm{O}_{3}$ mixing ratio at that altitude is $142.4 \mathrm{ppbv}$ in 2010 and $167.9 \mathrm{ppbv}$ in 2013 . The magnitudes of $\mathrm{O}_{3}$ mixing ratios from these balloonborne sonde measurements support those from MLS; $\mathrm{O}_{3}$ mixing ratios in the UTLS are less than $200 \mathrm{ppbv}$ over the TP/SASM region. 


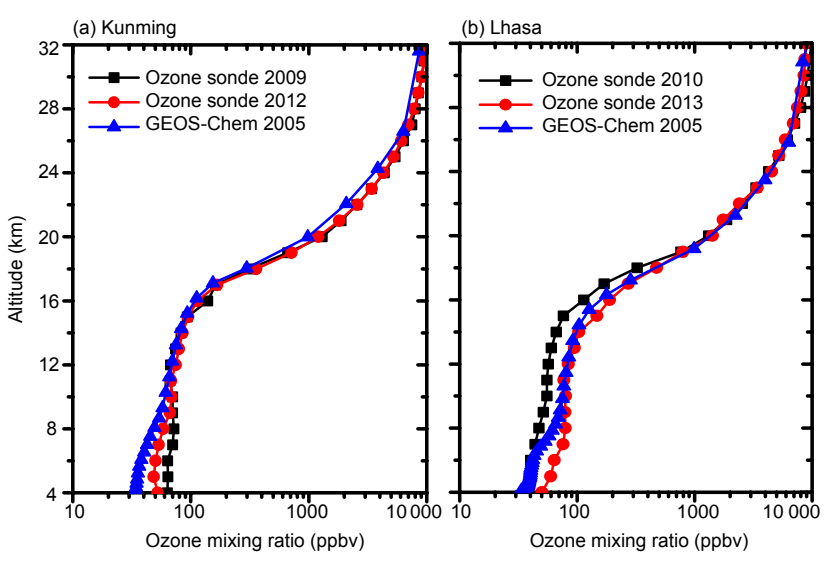

Figure 6. The simulated and observed vertical profiles of monthly mean $\mathrm{O}_{3}$ mixing ratios at (a) Kunming and (b) Lhasa in August. The model results are from the simulation of year 2005. The observations in Kunming were conducted during 7-13 August (11 profiles of $\mathrm{O}_{3}$ collected) in 2009 and during 12-31 August in 2012 (daily observations). The observations in Lhasa were conducted during 22-28 August in 2010 (12 profiles of $\mathrm{O}_{3}$ collected) and during 4-26 August in 2013 (daily observations).

\section{Simulated aerosols and model evaluation}

\subsection{Simulated aerosols}

Figure 7a shows the simulated surface-layer concentrations of $\mathrm{SO}_{4}^{2-}, \mathrm{NO}_{3}^{-}, \mathrm{NH}_{4}^{+}, \mathrm{OC}, \mathrm{BC}$, and $\mathrm{PM}_{2.5}$ (the sum of the mass of $\mathrm{SO}_{4}^{2-}, \mathrm{NO}_{3}^{-}, \mathrm{NH}_{4}^{+}, \mathrm{BC}$, and $\mathrm{OC}$ aerosols) averaged over June-August of year 2005. As expected, simulated aerosol concentrations are high over polluted regions such as India and eastern China as a result of the high anthropogenic emissions of aerosol precursors and aerosols (Streets et al., 2003; Huang et al., 2012). Over the TP/SASM region $\left(70-105^{\circ} \mathrm{E}, 10-40^{\circ} \mathrm{N}\right)$, the average concentrations of $\mathrm{SO}_{4}^{2-}$, $\mathrm{NO}_{3}^{-}, \mathrm{NH}_{4}^{+}, \mathrm{BC}$, and $\mathrm{OC}$ are $1.70,0.94,0.85,0.30$, and $0.94 \mu \mathrm{g} \mathrm{m}^{-3}$, respectively. $\mathrm{NO}_{3}^{-}$is simulated to be of secondary importance at the surface over the region of our interest. The simulated distributions and magnitudes of these aerosol species are similar to those reported in Wang et al. (2013) and $\mathrm{Mu}$ and Liao (2014).

Figure $7 \mathrm{~b}$ and $\mathrm{c}$ also show the simulated concentrations of $\mathrm{SO}_{4}^{2-}, \mathrm{NO}_{3}^{-}, \mathrm{NH}_{4}^{+}, \mathrm{OC}, \mathrm{BC}$, and $\mathrm{PM}_{2.5}$ in the UTLS. Elevated concentrations of $\mathrm{SO}_{4}^{2-}, \mathrm{NO}_{3}^{-}, \mathrm{NH}_{4}^{+}, \mathrm{OC}, \mathrm{BC}$, and $\mathrm{PM}_{2.5}$ are simulated over the TP and the plateau south slope at $200 \mathrm{hPa}$ altitude, and extend from the eastern Mediterranean to western China at $100 \mathrm{hPa}$. The simulated enhanced concentrations of $\mathrm{SO}_{4}^{2-}, \mathrm{OC}$, and $\mathrm{BC}$ at $100 \mathrm{hPa}$ over the anticyclone region $\left(20-120^{\circ} \mathrm{E}, 10-40^{\circ} \mathrm{N}\right)$ agree with previous observational and modeling studies (Lelieveld et al., 2001; Li et al., 2005; Fadnavis et al., 2013). Li et al. (2005) reported elevated $\mathrm{CO}$ concentrations in the upper troposphere over the $\mathrm{TP}$, on the basis of both MLS measurements and the GEOS-
Chem simulation for September 2004. Fadnavis et al. (2013) also simulated maximum concentrations of $\mathrm{SO}_{4}^{2-}$, OC, $\mathrm{BC}$, and mineral dust aerosols in the UTLS during the Asian summer monsoon season owing to convective uplifting of the boundary layer pollutants. With $\mathrm{NO}_{3}^{-}$aerosol accounted for in our simulation, $\mathrm{NO}_{3}^{-}$is simulated to be the most dominant aerosol species in the UTLS over the TP/SASM region, followed by $\mathrm{SO}_{4}^{2-}, \mathrm{NH}_{4}^{+}, \mathrm{OC}$, and BC. At $100 \mathrm{hPa}$, the averaged concentrations of $\mathrm{SO}_{4}^{2-}, \mathrm{NO}_{3}^{-}, \mathrm{NH}_{4}^{+}, \mathrm{OC}$, and $\mathrm{BC}$ over the $\mathrm{TP} / \mathrm{SASM}$ region $\left(70-105^{\circ} \mathrm{E}, 10-40^{\circ} \mathrm{N}\right)$ region are 0.026 , $0.069,0.014,0.011$, and $0.002 \mu \mathrm{g} \mathrm{m}^{-3}$, respectively.

\subsection{Comparisons of simulated aerosol concentrations with in situ observations}

The simulated aerosol concentrations in East Asia in the GEOS-Chem model have been evaluated in previous studies (L. Zhang et al., 2010; Fu et al., 2012; Jeong and Park, 2013; Jiang et al., 2013; Wang et al., 2013; Lou et al., 2014). Here we are focused on the evaluation of aerosols in the South Asian monsoon region. For lack of publicly accessible in situ measurements of summertime aerosols in the South Asia monsoon area, we compiled monthly or seasonal mean measured concentrations of each aerosol species based on measurements reported in the literature (see Table S1 in the Supplement). These measurements were carried out over the years of 1992-2010. The locations of sites with measurements available are shown in Fig. 8a. Most sites are located in the upwind directions of the TP, with pollutants that can be transported to the UTLS during the South Asian summer monsoon season. The observed $\mathrm{PM}_{10}$ concentrations listed in Table $\mathrm{S} 1$ are multiplied by 0.6 to convert to $\mathrm{PM}_{2.5}$ for model evaluation, following the suggestions in Zhang et al. (2002) and Chatterjee et al. (2010).

Figure $8 \mathrm{~b}-\mathrm{f}$ show the scatter plots of simulated vs. observed seasonal mean aerosol concentrations. Compared with measurements, simulated $\mathrm{SO}_{4}^{2-}, \mathrm{NO}_{3}^{-}, \mathrm{NH}_{4}^{+}, \mathrm{OC}$, and $\mathrm{BC}$ have NMBs of $-17.0,+38.8,+42.0,-69.7$, and $-41.0 \%$, respectively, as the concentrations of all seasons are considered. The correlations between model results and observations have $R$ values of $0.49-0.85$ for all aerosol species, indicating that the model is capable of capturing the spatial distributions and seasonal variations of each aerosol species in the South Asian monsoon region despite the biases in concentrations. If we consider simulated and measured concentrations for JJA alone, the simulated concentrations of $\mathrm{SO}_{4}^{2-}, \mathrm{NO}_{3}^{-}, \mathrm{NH}_{4}^{+}, \mathrm{OC}$, and $\mathrm{BC}$ exhibit seasonal NMBs of $-14.7,+51.5,+74.9,-57.2$, and $-32.2 \%$, respectively, and the values of $R$ are in the range of $0.24-0.85$. Note that the measurements of $\mathrm{NO}_{3}^{-}$and $\mathrm{NH}_{4}^{+}$are quite limited in terms of the number of samples, and the discrepancies between model results and measurements may also arise from the mismatch of the model year 2005 with the years of 1992-2010 with observations available. 


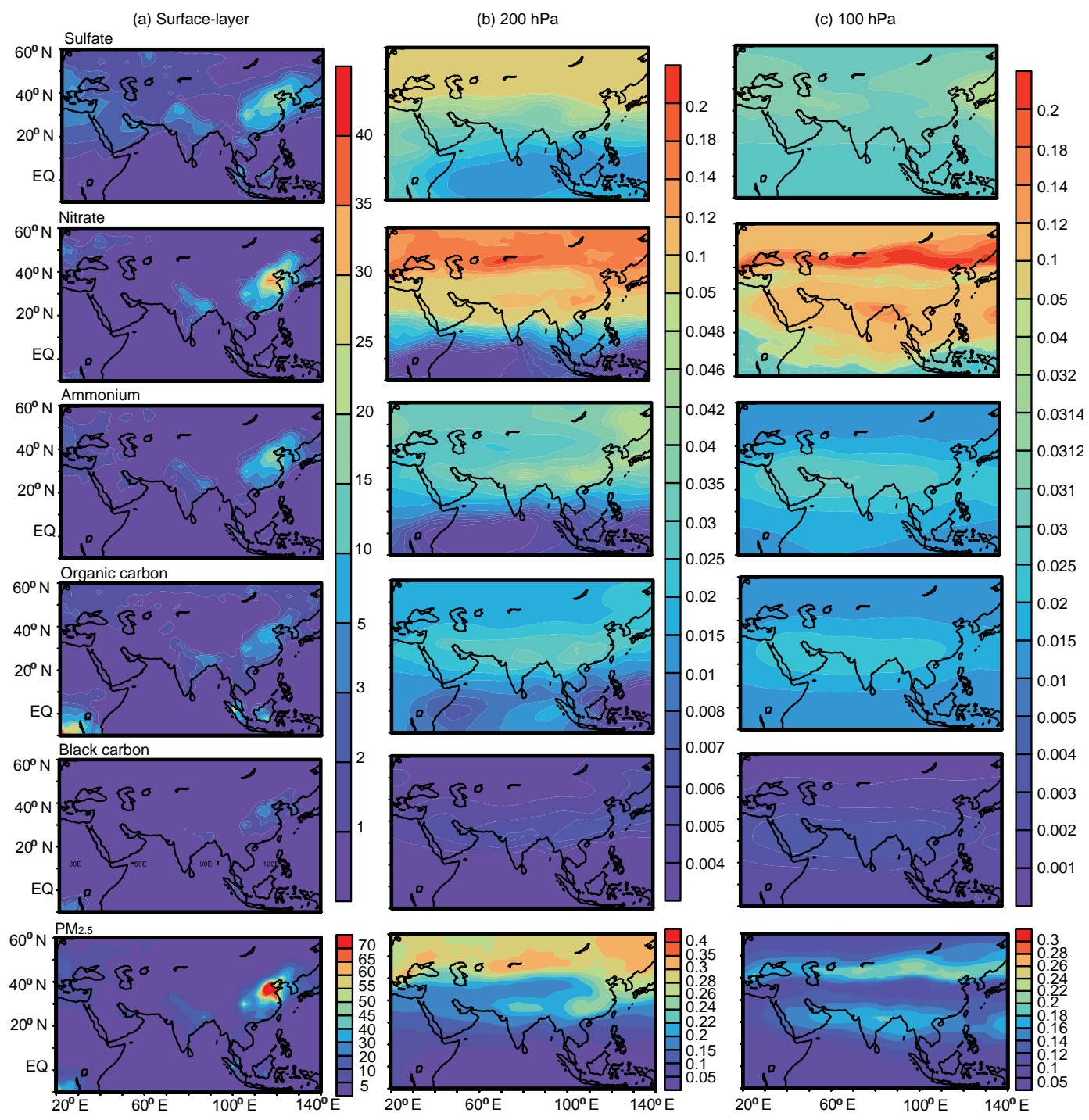

Figure 7. Simulated seasonal mean concentrations $\left(\mu \mathrm{g} \mathrm{m}^{-3}\right)$ of sulfate, nitrate, ammonium, organic carbon, black carbon, and PM $2.5(\mathrm{defined}$ as the sum of sulfate, nitrate, ammonium, BC, and OC) at (a) the surface layer, (b) $200 \mathrm{hPa}$, and (c) $100 \mathrm{hPa}$, during summer (June-August) of year 2005. Note that color bars are different for concentrations at the surface, 200 , and $100 \mathrm{hPa}$.

\subsection{Comparisons of simulated aerosol extinction coefficients with SAGE II data sets}

Satellite data sets from the Stratospheric Aerosol and Gas Experiment II (SAGE II, https://eosweb.larc.nasa.gov/ project/sage2/sage2_v620_table) are used to evaluate the simulated aerosol extinction in the UTLS. The SAGE II instrument was launched in October 1984 aboard the Earth Radiation Budget Satellite (ERBS) and terminated on 8 September 2005 (McCormick, 1987; Chu et al., 1989). The data sets used here are aerosol extinction coefficients at $525 \mathrm{~nm}$ from the version 6.20 SAGE retrievals, covering from 0.5 to $40 \mathrm{~km}$ with a vertical resolution of $0.5 \mathrm{~km}$. Many validation studies have been conducted on the SAGE II aerosol data (Russell and McCormick, 1989; Oberbeck et al.,
1989; Wang et al., 1989), which indicated that extinction coefficients have uncertainties of 20-30\%. The extinction coefficients of aerosols in the GEOS-Chem model are calculated using aerosol mass concentration, extinction efficiency, effective radius, particle mass density, and the assumed aerosol size distribution (Drury et al., 2010). The hygroscopic growth of each aerosol species with relative humidity is accounted for, using the hygroscopic growth factors listed in Martin et al. (2003).

Figure 9a presents the simulated monthly mean distribution of aerosol extinction coefficients at $100 \mathrm{hPa}$ for July of 2005 . At $100 \mathrm{hPa}$, the simulated aerosol extinction coefficients are relatively high over the anticyclone region, where anthropogenic aerosol species (Fig. 7) and natural aerosols such as mineral dust and sea salt contribute to aerosol ex- 

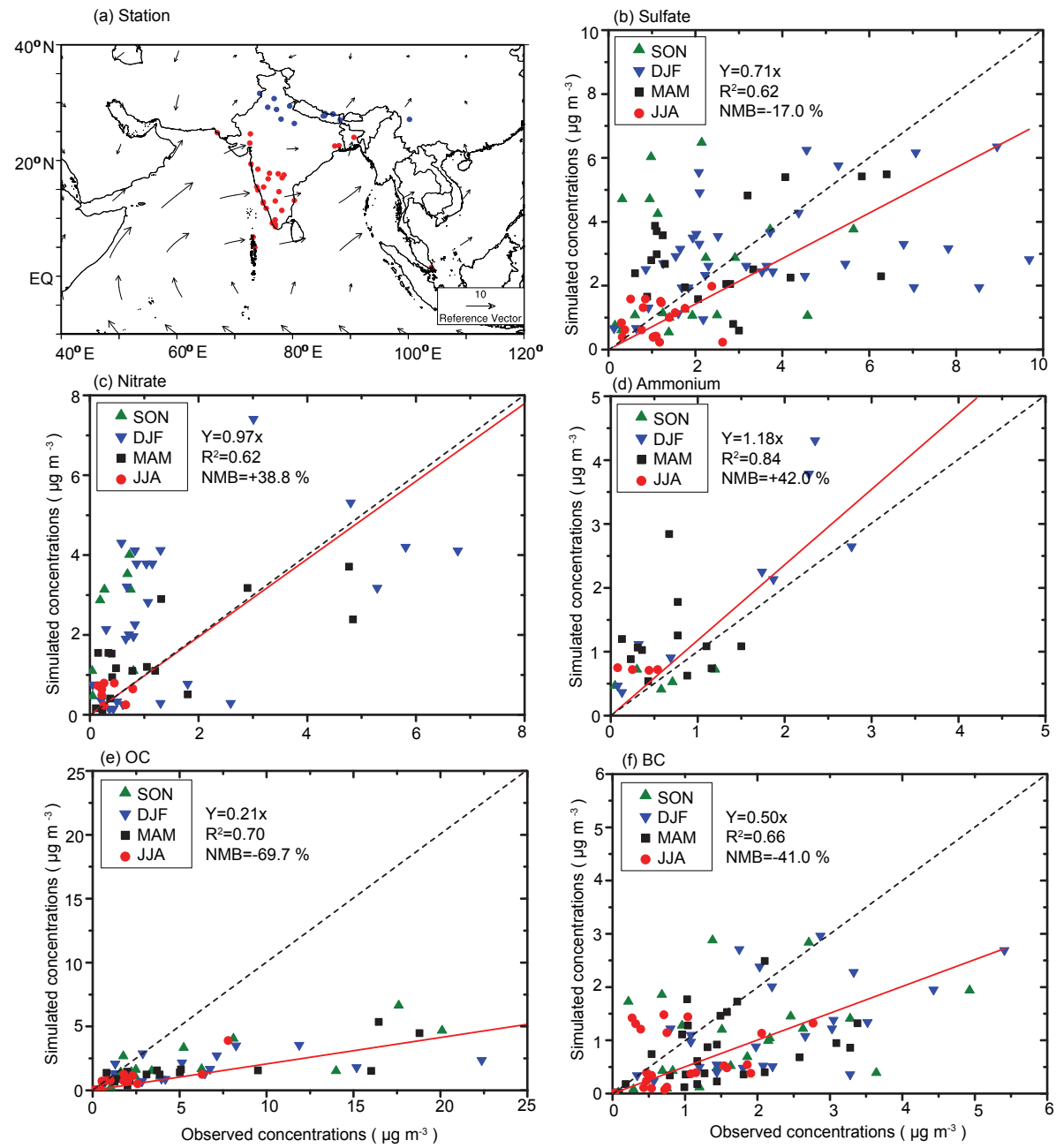

Figure 8. (a) Locations with measured aerosol concentrations from previous studies. Surface winds during summertime are also shown. Panels (b)-(f) show the comparisons of simulated seasonal mean concentrations of sulfate, nitrate, ammonium, OC, and BC with measured values, respectively. In (b)-(f) the $1: 1$ line (dashed), linear fit (solid line and equation), correlation coefficient between simulated and measured concentrations $(R)$, and normalized mean bias (NMB) (defined as NMB $=\frac{\sum_{i=1}^{n}\left(P_{i}-O_{i}\right)}{\sum_{i=1}^{n} O_{i}} \times 100 \%$, where $P_{i}$ and $O_{i}$ are predicted and observed concentrations at station $i$ for each aerosol species) are also shown.

tinction coefficients in summer. Note that the contributions of sulfate, nitrate, ammonium, OC, sea salt, and mineral dust are all considered when we calculate aerosol extinction coefficients. Aerosol extinction coefficients are simulated to be $1.2-2 \times 10^{-3} \mathrm{~km}^{-1}$ at $100 \mathrm{hPa}$ over the Asian continent and Indian Ocean $\left(20^{\circ} \mathrm{S}-30^{\circ} \mathrm{N}, 30-105^{\circ} \mathrm{E}\right)$. These values agree closely with aerosol extinction coefficients measured at Naqu during August of 2011 for the same altitude, the maximum of which was $2.4 \times 10^{-3} \mathrm{~km}^{-1}$ (He et al., 2014). Vernier et al. (2011) also identified this Asian aerosol layer with high SR at $100 \mathrm{hPa}$ by observations of CALIPSO for JJA of 20062008.

Figure $9 \mathrm{~b}$ displays the monthly mean vertical profiles of aerosol extinction coefficients averaged over the Asian mon- soon anticyclone region $\left(20-120^{\circ} \mathrm{E}, 10-40^{\circ} \mathrm{N}\right)$ (Fig. 1) for July of 2005. The SAGE II data sets are available for July only in 2005. The profiles from SAGE II and the GEOSChem simulation are all shown. The vertical distributions of aerosol extinction coefficients with nitrate and without nitrate are both from the baseline run with full chemistry. The vertical distribution of aerosol extinction coefficient with nitrate (or without nitrate) indicates that the contribution of nitrate aerosol to aerosol extinction is (or is not) accounted for. Accounting for all aerosol species, the GEOS-Chem model reproduces the aerosol extinction coefficients above $10 \mathrm{~km}$ well, but the discrepancies are rather large in altitudes less than $10 \mathrm{~km}$. Note that the uncertainties in satellite data sets increase as the altitude decreases (Vanhellemont et al., 2008; 
Kulkarni and Ramachandran, 2015), and the missing data in the lower troposphere along the satellite trajectories over the region of our interest also contribute to the discrepancies.

Comparisons of profiles of aerosol extinction coefficients with and without nitrate aerosol indicate that the profiles show small differences in altitudes less than $6 \mathrm{~km}$ but large discrepancies from $6 \mathrm{~km}$ to the tropopause. With nitrate aerosol accounted for, the simulated aerosol extinction coefficients agree closely with SAGE II data sets in the UTLS (averaged over 14-16 km, the simulated value is $8.6 \times 10^{-4} \mathrm{~km}^{-1}$, while the observed value is $\left.8.0 \times 10^{-4} \mathrm{~km}^{-1}\right)$. Without nitrate aerosol, the simulated aerosol extinction coefficient at $14-16 \mathrm{~km}$ altitude is $1.5 \times 10^{-4} \mathrm{~km}^{-1}$, which underestimates the aerosol extinction coefficient by $82.6 \%$ compared to that calculated with all the aerosol species. These comparisons of extinction coefficients with and without nitrate aerosol suggest that nitrate aerosol plays an important role in aerosol extinction in the UTLS over the region of our interest.

\section{Contribution of nitrate to aerosol concentrations in the UTLS}

Since nitrate aerosol is simulated to be the most abundant aerosol species in the UTLS over the TP/SASM region, we analyze the contribution of nitrate to $\mathrm{PM}_{2.5}$ concentration $\left(C_{\mathrm{NIT}}=\right.$ nitrate concentration $\times 100 \% / \mathrm{PM}_{2.5}$ concentration) in this section. Figure 10 shows the simulated seasonal mean distributions of $C_{\mathrm{NIT}}$ for June-August of year 2005. At the surface layer (Fig. 10a), simulated high $C_{\text {NIT }}$ values are located over the areas with high nitrate concentrations (India and eastern China) as well as the oceans where $\mathrm{NO}_{3}^{-}$also forms on sea salt and mineral dust particles (Arimoto et al., 1996; Nakamura et al., 2005; George and Nair, 2008). Over the TP/SASM region, the $C_{\text {NIT }}$ values in JJA are $5-35 \%$ at the surface, $25-50 \%$ at $200 \mathrm{hPa}$ (Fig. 10b), and could exceed $60 \%$ at $100 \mathrm{hPa}$ (Fig. 10c). The latitudealtitude cross section of $C_{\text {NIT }}$ (Fig. 10d) shows that $C_{\text {NIT }}$ over $20-40^{\circ} \mathrm{N}$ increases with altitude and reaches maximum values around the extratropical tropopause.

Table 2 lists the mean concentrations of $\mathrm{SO}_{4}^{2-}, \mathrm{NO}_{3}^{-}$, $\mathrm{NH}_{4}^{+}, \mathrm{BC}$, and $\mathrm{OC}$, and their contributions to $\mathrm{PM}_{2.5}$ during summertime of 2005 over the TP/SASM, TP, and SASM regions. Over the TP/SASM region $\mathrm{SO}_{4}^{2-}, \mathrm{NO}_{3}^{-}, \mathrm{NH}_{4}^{+}, \mathrm{BC}$, and $\mathrm{OC}$ are simulated to contribute $35.9,19.8,18.1,6.4$, and $19.8 \%$, respectively, to $\mathrm{PM}_{2.5}$ mass concentration at the surface layer. The contributions increase significantly in the UTLS. The largest $C_{\mathrm{NIT}}$ is simulated in the SASM region at $100 \mathrm{hPa}$, where $\mathrm{NO}_{3}^{-}$accounts for $60.5 \%$ of $\mathrm{PM}_{2.5}$ mass concentration. The high $C_{\text {NIT }}$ values indicate that $\mathrm{NO}_{3}^{-}$plays an important role in the aerosol layer in the UTLS over the TP/SASM region.

Considering the large uncertainties in simulated sea salt (Jaeglé et al., 2011) and mineral dust (Fairlie et al., 2007) aerosols, we tend to be focused on anthropogenic aerosol species $\left(\mathrm{SO}_{4}^{2-}, \mathrm{NO}_{3}^{-}, \mathrm{NH}_{4}^{+}, \mathrm{BC}\right.$, and $\left.\mathrm{OC}\right)$ in this work. In our model, concentrations of sea salt (or mineral dust) are simulated to be $1.0-1.7 \mathrm{ng} \mathrm{m}^{-3}$ (or 5.0-7.0 $\mathrm{ng} \mathrm{m}^{-3}$ ) over the studied region in the summer of 2005, which contribute less than $1.2 \%$ (or $5.0 \%$ ) to total aerosol mass at $100 \mathrm{hPa}$. Therefore the consideration of sea salt and mineral dust can slightly reduce $C_{\text {NIT }}$ values, but $C_{\text {NIT }}$ values at $100 \mathrm{hPa}$ are still as high as $45-65 \%$ over the TP/SASM region in summer.

\section{Mechanisms for high nitrate concentrations in the UTLS}

\subsection{Upward transport of nitrate from the lower troposphere}

The intense convective transport of chemical species into the UTLS over the TP/SASM region during summertime has been widely discussed in previous studies (Randel et al., 2010; Bian et al., 2011a; Fadnavis et al., 2013, 2015; Qie et al., 2014; He et al., 2014), evidenced by both the satellite observations (Fu et al., 2006; Luo et al., 2011) and the calculation of the outgoing long-wave radiation which is a convective proxy over the region (Randel and Park, 2006; Park et al., 2007; Fadnavis et al., 2013). Since nitrate aerosol is simulated to be of secondary abundant aerosol species in the surface layer over the TP/SASM region (Fig. 7), the vertical mass transport through the deep convection in this region contributes to the accumulation of $\mathrm{NO}_{3}^{-}$in the UTLS. Figure 11 shows the latitude-altitude cross sections of simulated concentrations of $\mathrm{SO}_{4}^{2-}$ and $\mathrm{NO}_{3}^{-}$averaged over 70 $105^{\circ} \mathrm{E}$ in June-August of 2005 , together with the wind vectors obtained from the European Centre for MediumRange Weather Forecasts (ECMWF) ERA-Interim Reanalysis data. Note that the assimilated GEOS-5 meteorological fields do not have vertical winds (http://wiki.seas.harvard. edu/geos-chem/index.php/List_of_GEOS-5_met_fields), so we use the ECMWF reanalysis wind fields to do the analysis here. High values of aerosol concentrations are found on the south slope of the Himalayas, where the deep convection exists. Although both $\mathrm{SO}_{4}^{2-}$ and $\mathrm{NO}_{3}^{-}$are transported upward to the extratropical tropopause, the details of the vertical distributions are different. At altitudes higher than $8 \mathrm{~km}$, the concentrations of $\mathrm{NO}_{3}^{-}$do not decrease with altitude as quickly as those of $\mathrm{SO}_{4}^{2-}$, and the concentrations of $\mathrm{NO}_{3}^{-}$ over $10-40^{\circ} \mathrm{N}$ are higher than those of $\mathrm{SO}_{4}^{2-}$.

The chemical mechanisms for the formation of $\mathrm{SO}_{4}^{2-}$ $\mathrm{NO}_{3}^{-}$, and $\mathrm{NH}_{4}^{+}$aerosols in the GEOS-Chem model were described in R. J. Park et al. (2004), which are comprehensive and have been used extensively in previous studies to simulate these three aerosol species (R. J. Park et al., 2004; Pye et al., 2009; L. Zhang et al., 2010; Zhu et al., 2012; Jiang et al., 2013; Lou et al., 2014). Sulfate aerosol forms from gas-phase oxidation of $\mathrm{SO}_{2}$ by $\mathrm{OH}$ and from in-cloud oxidation of 
(a)
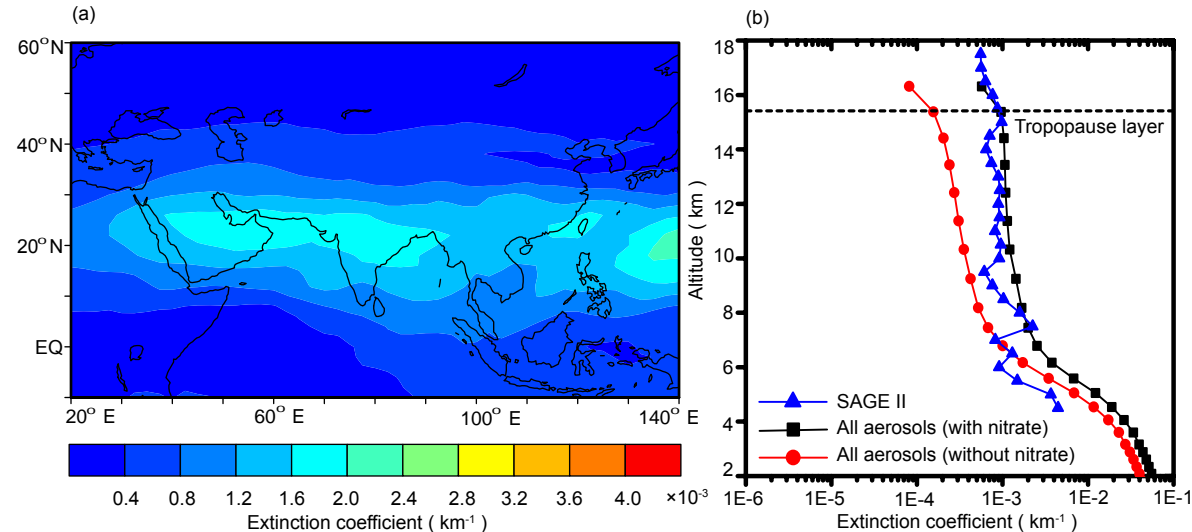

Figure 9. (a) Monthly mean distribution of aerosol extinction coefficients $\left(\mathrm{km}^{-1}\right)$ at $100 \mathrm{hPa}$ for July of 2005 . (b) Monthly mean vertical distributions of aerosol extinction coefficients (at $525 \mathrm{~nm}$ for SAGE II and $550 \mathrm{~nm}$ for GEOS-Chem, with the contributions of both anthropogenic and natural aerosols considered) $\left(\mathrm{km}^{-1}\right)$ averaged over the Asian monsoon anticyclone region $\left(20-120^{\circ} \mathrm{E}, 10-40^{\circ} \mathrm{N}\right)$ for July of 2005. The horizontal dashed line represents the tropopause averaged over the Asian monsoon anticyclone region simulated by the GEOS-Chem model.

Table 2. Simulated seasonal mean concentrations of aerosols and their contributions to $\mathrm{PM}_{2.5}$ (in percentages in parentheses) during summertime (June-August) of 2005 for the TP/SASM, TP, and SASM regions. The unit is $\mu \mathrm{g} \mathrm{m}^{-3}$ for concentrations at the surface, and $10^{-2} \mu \mathrm{g} \mathrm{m}{ }^{-3}$ for concentrations at 200 and $100 \mathrm{hPa}$.

\begin{tabular}{|c|c|c|c|c|c|c|}
\hline & $\mathrm{PM}_{2.5}$ & $\mathrm{SO}_{4}^{2-}$ & $\mathrm{NO}_{3}^{-}$ & $\mathrm{NH}_{4}^{+}$ & OC & $\mathrm{BC}$ \\
\hline \multicolumn{7}{|c|}{ TP/SASM } \\
\hline Surface & 4.73 & $1.70(35.9 \%)$ & $0.94(19.8 \%)$ & $0.85(18.1 \%)$ & $0.94(19.8 \%)$ & $0.30(6.4 \%)$ \\
\hline $200 \mathrm{hPa}$ & 16.19 & $3.27(20.2 \%)$ & $7.57(46.8 \%)$ & $2.67(16.5 \%)$ & $2.22(13.7 \%)$ & $0.44(2.7 \%)$ \\
\hline $100 \mathrm{hPa}$ & 12.14 & $2.60(21.4 \%)$ & $6.90(56.8 \%)$ & $1.43(11.8 \%)$ & $1.05(8.6 \%)$ & $0.16(1.3 \%)$ \\
\hline \multicolumn{7}{|c|}{$\mathrm{TP}$} \\
\hline Surface & 5.44 & $2.12(39.0 \%)$ & $1.05(19.3 \%)$ & $1.08(19.9 \%)$ & $0.88(16.1 \%)$ & $0.31(5.7 \%)$ \\
\hline $200 \mathrm{hPa}$ & 19.80 & $4.16(21.0 \%)$ & $9.43(47.6 \%)$ & $3.25(16.4 \%)$ & $2.49(12.6 \%)$ & $0.47(2.4 \%)$ \\
\hline $100 \mathrm{hPa}$ & 10.58 & $2.60(24.6 \%)$ & $5.51(52.0 \%)$ & $1.35(12.7 \%)$ & $0.99(9.4 \%)$ & $0.14(1.3 \%)$ \\
\hline \multicolumn{7}{|c|}{ SASM } \\
\hline Surface & 4.02 & $1.28(31.8 \%)$ & $0.83(20.5 \%)$ & $0.63(15.6 \%)$ & $1.00(24.8 \%)$ & $0.29(7.2 \%)$ \\
\hline $200 \mathrm{hPa}$ & 12.57 & $2.38(18.9 \%)$ & $5.72(45.5 \%)$ & $2.10(16.7 \%)$ & $1.95(15.5 \%)$ & $0.41(3.3 \%)$ \\
\hline $100 \mathrm{hPa}$ & 13.71 & $2.60(19.0 \%)$ & $8.30(60.5 \%)$ & $1.52(11.1 \%)$ & $1.11(8.1 \%)$ & $0.18(1.3 \%)$ \\
\hline
\end{tabular}

$\mathrm{SO}_{2}$ by $\mathrm{O}_{3}$ and $\mathrm{H}_{2} \mathrm{O}_{2}$. Nitrate forms from the partitioning of $\mathrm{HNO}_{3}$ between gas and aerosol phases, which is calculated by the ISORROPIA II thermodynamic equilibrium module (Fountoukis and Nenes, 2007) in the GEOS-Chem model. $\mathrm{HNO}_{3}$ is produced by the reaction of $\mathrm{NO}_{2}$ with $\mathrm{OH}$ during daytime and by hydrolysis of $\mathrm{N}_{2} \mathrm{O}_{5}$ on aerosol surfaces at night (Table 3). The chemical mechanisms for $\mathrm{SO}_{4}^{2-}$ and $\mathrm{NO}_{3}^{-}$have different sensitivity to meteorological conditions. During the vertical transport, temperature decreases, which reduces the gas-phase oxidation of $\mathrm{SO}_{2}$ (Yao et al., 2002; Seinfeld and Pandis, 2006) but promotes the formation of $\mathrm{NO}_{3}^{-}$by shifting gas-particle equilibria (Dawson et al., 2007; Liao et al., 2009). Dawson et al. (2007) examined the sensitivities of sulfate and nitrate concentrations to temperature by using the Particulate Matter Comprehensive Air Quality Model with extensions (PMCAMx). The sensitivity test was performed by fixing all meteorological parameters but perturbing temperature. Their sensitivity simulations showed that the increases in temperature led to increases in sulfate concentrations and decreases in nitrate concentrations. Compared to nitrate, sulfate concentrations showed smaller sensitivity to temperature changes (Dawson et al., 2007); as temperature increased, nitrate concentrations decreased by 19 and $17 \% \mathrm{~K}^{-1}$ in January and July respectively, while sulfate concentration increased by 0.12 and $1.3 \% \mathrm{~K}^{-1}$ in January and July, respectively. Therefore the different chemical mechanisms for $\mathrm{SO}_{4}^{2-}$ and $\mathrm{NO}_{3}^{-}$formation contribute to the differences in their vertical distributions. 

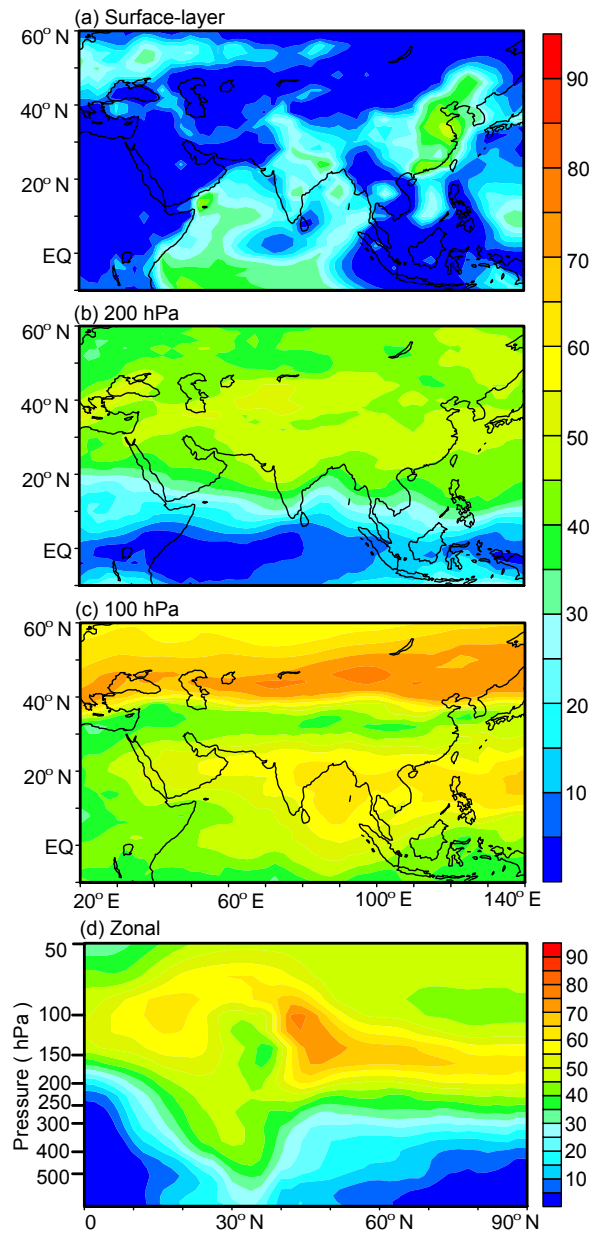

Figure 10. Simulated contributions of nitrate to $\mathrm{PM}_{2.5}$ $\left(C_{\mathrm{NIT}}=[\mathrm{NIT}] /\left[\mathrm{PM}_{2.5}\right] \times 100 \%\right)$ averaged over summer (JuneAugust) of year 2005 at (a) the surface layer, (b) $200 \mathrm{hPa}$, and (c) $100 \mathrm{hPa}$. (d) The latitude-altitude cross section of simulated $C_{\text {NIT }}(\%)$ averaged over $70-105^{\circ} \mathrm{E}$.

\subsection{Net chemical production of $\mathrm{HNO}_{3}$ during the vertical transport}

As mentioned above, the formation of gas-phase $\mathrm{HNO}_{3}$ and the partitioning of $\mathrm{HNO}_{3}$ between gas and aerosol phases are the two major chemical processes that influence $\mathrm{NO}_{3}^{-}$concentrations. The ability of the GEOS-Chem model to simulate gas-phase $\mathrm{HNO}_{3}$ has been evaluated in Sect. 3.1 (by comparisons of our model results with MLS observations and concentrations from previous modeling studies). Major reactions for the production and loss of $\mathrm{HNO}_{3}$ are listed in Table 3. Figure 12 shows the net chemical production of $\mathrm{HNO}_{3}$ by gas-phase reactions and heterogeneous reactions (chemical production by Reactions (R1)-(R23) minus chemical loss by Reactions (R24)-(R25) in Table 3) summed over the TP/SASM region. The net chemical production has an overall trend of decreasing with altitude. Since $\mathrm{NO}_{x}$ emis-
Table 3. List of gas-phase reactions and heterogeneous reactions involve $\mathrm{HNO}_{3}$ in the GEOS-Chem model (Version 9-01-03).

\begin{tabular}{|c|c|c|c|}
\hline & \multicolumn{2}{|l|}{ Reactants } & Products \\
\hline \multicolumn{4}{|c|}{ Chemical productions } \\
\hline Reaction (R1) & $\mathrm{NO}_{2}+\mathrm{OH}+\mathrm{M}$ & $\rightarrow$ & $\mathrm{HNO}_{3}+\mathrm{M}$ \\
\hline Reaction (R2) & $\mathrm{NO}_{3}+\mathrm{CH}_{2} \mathrm{O}$ & $\rightarrow$ & $\mathrm{HNO}_{3}+$ prod. \\
\hline Reaction (R3) & $\mathrm{ALD}_{2}+\mathrm{NO}_{3}$ & $\rightarrow$ & $\mathrm{HNO}_{3}+$ prod. \\
\hline Reaction (R4) & $\mathrm{RIO}_{1}+\mathrm{NO}$ & $\rightarrow$ & $\mathrm{HNO}_{3}+$ prod. \\
\hline Reaction (R5) & $\mathrm{IAO}_{2}+\mathrm{NO}$ & $\rightarrow$ & $0.08 \mathrm{HNO}_{3}+$ prod. \\
\hline Reaction (R6) & $\mathrm{ISN}_{1}+\mathrm{NO}$ & $\rightarrow$ & $0.05 \mathrm{HNO}_{3}+$ prod. \\
\hline Reaction (R7) & $\mathrm{VRO}_{2}+\mathrm{NO}$ & $\rightarrow$ & $\mathrm{HNO}_{3}+$ prod. \\
\hline Reaction (R8) & $\mathrm{MRO}_{2}+\mathrm{NO}$ & $\rightarrow$ & $\mathrm{HNO}_{3}+$ prod. \\
\hline Reaction (R9) & $\mathrm{INO}_{2}+\mathrm{NO}$ & $\rightarrow$ & $0.85 \mathrm{HNO}_{3}+$ prod. \\
\hline Reaction (R10) & $\mathrm{ALK}_{4}+\mathrm{NO}_{3}$ & $\rightarrow$ & $\mathrm{HNO}_{3}+$ prod. \\
\hline Reaction (R11) & $\mathrm{RCHO}+\mathrm{NO}_{3}$ & $\rightarrow$ & $\mathrm{HNO}_{3}+$ prod. \\
\hline Reaction (R12) & $\mathrm{MEK}+\mathrm{NO}_{3}$ & $\rightarrow$ & $\mathrm{HNO}_{3}+$ prod. \\
\hline Reaction (R13) & $\mathrm{INO}_{2}+\mathrm{MO}_{2}$ & $\rightarrow$ & $0.425 \mathrm{HNO}_{3}+$ prod. \\
\hline Reaction (R14) & $\mathrm{GLYX}+\mathrm{NO}_{3}$ & $\rightarrow$ & $\mathrm{HNO}_{3}+$ prod. \\
\hline Reaction (R15) & $\mathrm{MGLY}+\mathrm{NO}_{3}$ & $\rightarrow$ & $\mathrm{HNO}_{3}+$ prod. \\
\hline Reaction (R16) & $\mathrm{MACR}+\mathrm{NO}_{3}$ & $\rightarrow$ & $\mathrm{HNO}_{3}+$ prod. \\
\hline Reaction (R17) & $\mathrm{C}_{2} \mathrm{H}_{6}+\mathrm{NO}_{3}$ & $\rightarrow$ & $\mathrm{HNO}_{3}+$ prod. \\
\hline Reaction (R18) & $\mathrm{INO}_{2}+\mathrm{MCO}_{3}$ & $\rightarrow$ & $0.85 \mathrm{HNO}_{3}+$ prod. \\
\hline Reaction (R19) & $\mathrm{NO}_{2}+($ aerosol $)$ & $\rightarrow$ & $0.5 \mathrm{HNO}_{3}+$ prod. \\
\hline Reaction (R20) & $\mathrm{NO}_{3}+($ aerosol $)$ & $\rightarrow$ & $\mathrm{HNO}_{3}+$ prod. \\
\hline Reaction (R21) & $\mathrm{N}_{2} \mathrm{O}_{5}+($ aerosol $)$ & $\rightarrow$ & $2 \mathrm{HNO}_{3}$ \\
\hline Reaction (R22) & $\mathrm{DMS}+\mathrm{NO}_{3}$ & $\rightarrow$ & $\mathrm{HNO}_{3}+$ prod. \\
\hline Reaction (R23) & $\mathrm{BrNO}_{3}+\mathrm{H}_{2} \mathrm{O}(\mathrm{l}, \mathrm{s})$ & $\rightarrow$ & $\mathrm{HNO}_{3}+$ prod. \\
\hline \multicolumn{4}{|c|}{ Chemical loss } \\
\hline Reaction (R24) & $\mathrm{HNO}_{3}+\mathrm{OH}$ & $\rightarrow$ & $\mathrm{H}_{2} \mathrm{O}+\mathrm{NO}_{3}$ \\
\hline Reaction (R25) & $\mathrm{HNO}_{3}+h v$ & $\rightarrow$ & $\mathrm{OH}+\mathrm{NO}_{2}$ \\
\hline
\end{tabular}

sions from aircraft and lightning are located between 200 and $300 \mathrm{hPa}$ over the TP/SASM region during summer (Martin et al., 2007; Murray et al., 2012; Pitari et al., 2015), net chemical production of $\mathrm{HNO}_{3}$ shows a small peak at those altitudes. The mixing ratio of $\mathrm{HNO}_{3}$ decreases with altitude between 500 and $200 \mathrm{hPa}$ and increases with altitude above $200 \mathrm{hPa}$. At $100 \mathrm{hPa}$, the average $\mathrm{HNO}_{3}$ mixing ratio over the TP/SASM region agrees with the values of 300-400 pptv over the same region shown in Fig. 4.

Figure 12 also shows the transport of $\mathrm{HNO}_{3}$ over the TP/SASM region, defined as convergence of horizontal flux of $\mathrm{HNO}_{3}$ (inflow minus outflow) plus convergence of vertical flux of $\mathrm{HNO}_{3}$ (inflow minus outflow) for a specific vertical model layer. At altitudes below $200 \mathrm{hPa}$, concentrations of $\mathrm{HNO}_{3}$ over the TP/SASM region are dependent on the net chemical production by gas-phase reactions and heterogeneous reactions as well as the transport of $\mathrm{HNO}_{3}$. The vertical variation of the horizontal transport (the north-south and the east-west transport) follows the development of the anticyclone in the upper troposphere during summertime. As the altitude increases, the westerlies enhance over the TP and the easterlies develop over the SASM region (see Fig. 1 for our definitions of TP and SASM regions). At latitudes between 100 and $500 \mathrm{hPa}$, vertical transport of $\mathrm{HNO}_{3}$ occurs 
over the TP due to the deep convection activities over the region which can arrive at 100-200 hPa (Fig. 11; Fadnavis et al., 2013; Qie et al., 2014).

\subsection{The gas-to-aerosol conversion of $\mathrm{HNO}_{3}$ to form nitrate during the vertical transport}

$\mathrm{NO}_{3}^{-}$formation from gas-to-aerosol conversion of $\mathrm{HNO}_{3}$ is calculated by using the ISORROPIA II thermodynamic equilibrium module (Fountoukis and Nenes, 2007). As shown in Fig. 12, the nitrate formation from gas-to-aerosol conversion of $\mathrm{HNO}_{3}$ peaks between 100 and $300 \mathrm{hPa}$, indicating that the gas-aerosol partitioning plays an important role in the enhancement of nitrate in the UTLS.

The gas-to-aerosol conversion of $\mathrm{HNO}_{3}$ to form $\mathrm{NO}_{3}^{-}$is very sensitive to relative humidity $(\mathrm{RH})$ and temperature (Fountoukis and Nenes, 2007; Dawson et al., 2007). Low temperature and high $\mathrm{RH}$ are favorable for $\mathrm{NO}_{3}^{-}$formation. Figure 13 shows the seasonal mean horizontal distributions of RH and temperature at $100 \mathrm{hPa}$ and the latitude-altitude cross sections of these two parameters averaged over 70$105^{\circ} \mathrm{E}$. RH exhibits high values in the TP/SASM region, which are consistent with the high $\mathrm{H}_{2} \mathrm{O}$ mixing ratios in this area reported in Gettelman et al. (2004), M. Park et al. (2004), and Fu et al. (2006). At $100 \mathrm{hPa}$, the locations with high RH of exceeding $45 \%$ correspond well with those with high $C_{\text {NIT }}$ values (Fig. 10c). The latitude-altitude cross section of RH (Fig. 13c) shows that RH has high values over the places with intense upward transport (Fig. 11). For temperature, as Fig. 13b and d show, summertime temperatures are cold $(190-200 \mathrm{~K})$ at $100 \mathrm{hPa}$ in the TP/SASM region, consistent with the distribution and magnitude reported for August 2011, in He et al. (2014) on the basis of the NCEP Reanalysis data. The low temperatures over the TP/SASM region are associated with the adiabatic expansion of ascending air mass of the deep convections (Yanai et al., 1992; Park et al., 2007; He et al., 2014).

Because of the favorable conditions of RH and decreasing temperature, the gas-to-aerosol conversion of $\mathrm{HNO}_{3}$ to form nitrate can occur during the upward transport and in the UTLS. Figure 14 shows the mass budget for nitrate aerosol within the selected box of $70-105^{\circ} \mathrm{E}, 10-40^{\circ} \mathrm{N}, 8-16 \mathrm{~km}$ to see the role of nitrate formation over the TP/SASM region. The horizontal mass fluxes have a net negative value of $0.10 \mathrm{Tg}$ season $^{-1}$, reducing nitrate aerosol in the selected box. The vertical transport and the gas-to-aerosol conversion of $\mathrm{HNO}_{3}$ increase nitrate mass in the selected box, with values of 0.09 and $0.11 \mathrm{Tg}$ season $^{-1}$, respectively, indicating that the gas-to-aerosol conversion plays an important role in the enhancement of nitrate in the UTLS over the TP/SASM region. Although relatively high RH exists near the tropopause of the TP/SASM region, the air near the tropopause is still drier compared to that in the lower altitudes. Model results show that the gas-to-aerosol partition of $\mathrm{HNO}_{3}$ decreases with altitude between 100 and $300 \mathrm{hPa}$, indicating that the gas-to-aerosol conversion contributes to nitrate accumulation in the UTLS mainly during the process of upward transport.

Previous studies have also reported that nitric acid trihydrates (NAT, $\left.\mathrm{HNO}_{3} \cdot\left(\mathrm{H}_{2} \mathrm{O}\right)_{3}\right)$ could form in the polar and tropical stratosphere at low temperatures through two mechanisms: (1) the homogeneous nucleation out of supercooled ternary solutions, and (2) the heterogeneous formation on ice particles (Hofmann et al., 1989; Carslaw et al., 1998; Voigt et al., 2000; Popp et al., 2006; Kirner et al., 2011). A typical NAT condensation temperature is approximate $193 \mathrm{~K}$ (Kirner et al., 2011). As shown in Fig. 13, the temperatures around $100 \mathrm{hPa}$ over the TP/SASM region are in the range of 190$200 \mathrm{~K}$, which are low enough to produce some NAT particles. However, balloon-borne measurements of depolarization ratio and backscattering ratio of aerosols at Lhasa during August-October of 1999 by Kim et al. (2003) and Tobo et al. (2007) suggested that coarse and aspherical particles such as NAT are scarce in the UTLS of the TP/SASM.

\section{Sensitivities of simulated nitrate in the UTLS to anthropogenic $\mathrm{NO}_{x}, \mathrm{NH}_{3}$, and $\mathrm{SO}_{2}$ emissions in Asia}

Since simulated $\mathrm{SO}_{4}^{2-}, \mathrm{NO}_{3}^{-}$, and $\mathrm{NH}_{4}^{+}$concentrations have NMBs of, respectively, $-17.0,+38.8$, and $+42.0 \%$ on an annual mean basis and of $-14.7,+51.5$, and $+74.9 \%$ in summer (Sect. 4.2), we perform four sensitivity simulations to examine the impacts of uncertainties in surface-layer aerosol concentrations on simulated nitrate in the UTLS. In the first three cases, anthropogenic emissions of $\mathrm{NO}_{x}, \mathrm{NH}_{3}$, and $\mathrm{SO}_{2}$ in Asia are changed by $-50,-50$, and $+20 \%$, respectively, relative to those in our standard simulation. In the last case, anthropogenic emissions of all these three species are changed simultaneously, with $\mathrm{NO}_{x}$ reduced by $50 \%$, $\mathrm{NH}_{3}$ reduced by $50 \%$, and $\mathrm{SO}_{2}$ increased by $20 \%$ in Asia relative to the standard case. The purpose of these sensitivity studies is to reduce NMBs of simulated surface-layer concentrations of $\mathrm{SO}_{4}^{2-}, \mathrm{NO}_{3}^{-}$, and $\mathrm{NH}_{4}^{+}$and to see whether $\mathrm{NO}_{3}^{-}$is still the most dominant aerosol species in the UTLS. Model results from these sensitivity studies for summer of 2005 are presented in Table 4.

As anthropogenic emissions of $\mathrm{SO}_{2}$ in Asia are increased by $20 \%$, the NMB of simulated surface-layer $\mathrm{SO}_{4}^{2-}$ concentrations is $-4.4 \%$, which is an improvement compared to the NMB of $-14.7 \%$ in the standard simulation. However, the increases in $\mathrm{SO}_{2}$ emissions lead to larger NMBs of surfacelayer $\mathrm{NO}_{3}^{-}$and $\mathrm{NH}_{4}^{+}$because of the increased formation of ammonium sulfate or ammonium bisulfate. The percentage contributions of $\mathrm{SO}_{4}^{2-}$ to total aerosol mass in the UTLS increase slightly by $2.7 \%$ at $200 \mathrm{hPa}$ and by $1.6 \%$ at $100 \mathrm{hPa}$, and nitrate in the UTLS also shows small sensitivity to the change in $\mathrm{SO}_{2}$ emissions.

With anthropogenic emissions of $\mathrm{NO}_{x}$ in Asia reduced by $50 \%$, the NMB of simulated surface-layer $\mathrm{NO}_{3}^{-}$concentra- 


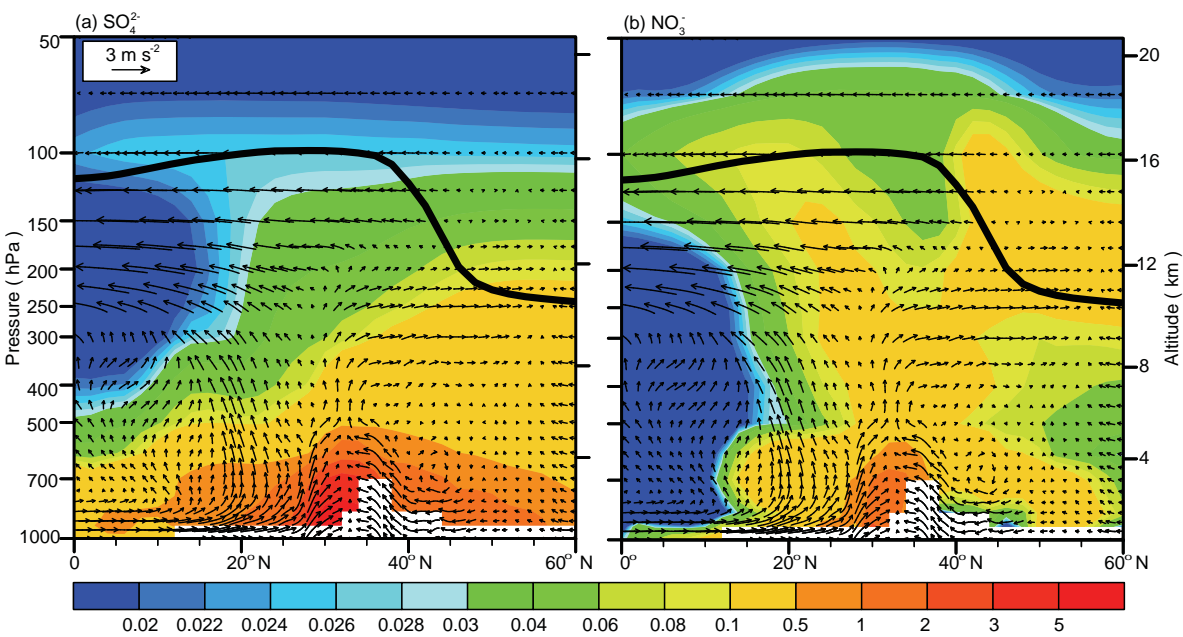

Figure 11. Latitude-altitude cross sections of simulated concentrations (color shades, $\mu \mathrm{g} \mathrm{m}^{-3}$ ) of $\mathrm{SO}_{4}^{2-}$ and $\mathrm{NO}_{3}^{-}$averaged over $70-105^{\circ} \mathrm{E}$ in June-August of 2005, together with the wind vectors obtained from the European Centre for Medium-Range Weather Forecasts (ECMWF) ERA-Interim Reanalysis data. The black line denotes the tropopause simulated by the GEOS-Chem model.

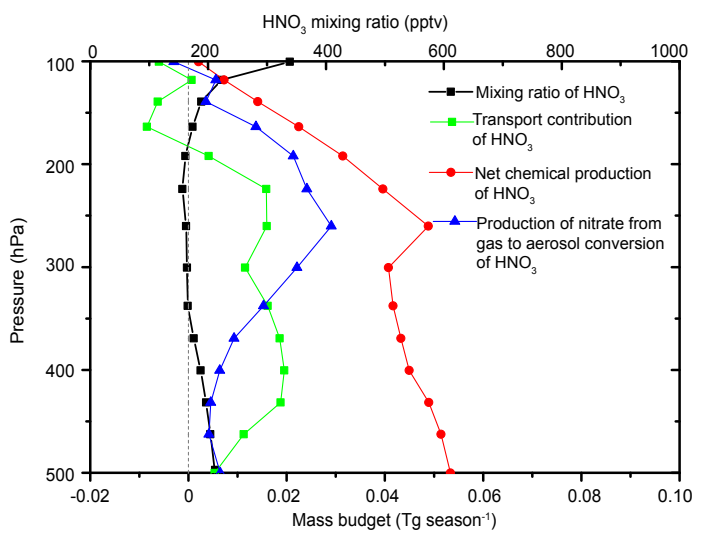

Figure 12. Profiles of the net chemical production of $\mathrm{HNO}_{3}$ by gas-phase reactions and heterogeneous reactions (red dotted line), the production of nitrate from gas-to-aerosol conversion of $\mathrm{HNO}_{3}$ (blue dotted line) and the transport contributions of $\mathrm{HNO}_{3}$ over the TP/SASM $\left(70-105^{\circ} \mathrm{E}, 10-40^{\circ} \mathrm{N}\right)$. The average $\mathrm{HNO}_{3}$ mixing ratios (black dotted line) are also shown over the TP/SASM region during summertime of year 2005 .

tions changes from $+51.5 \%$ in the standard simulation to $-11.7 \%$ in this sensitivity run. The contribution of each of $\mathrm{SO}_{4}^{2-}, \mathrm{NO}_{3}^{-}$, and $\mathrm{NH}_{4}^{+}$aerosols to total aerosol mass in the UTLS is not sensitive to this reduction in $\mathrm{NO}_{x}$ emissions at the surface; the percentage contribution obtained from this sensitivity run is very close to the value obtained in the standard simulation (Table 4). Similarly, in the sensitivity study with $\mathrm{NH}_{3}$ emissions reduced by $50 \%$ in Asia, simulated surface-layer concentrations of $\mathrm{NO}_{3}^{-}$and $\mathrm{NH}_{4}^{+}$are improved in terms of the values of NMBs, but the improvement in simulated aerosol concentrations at the surface layer does not in- fluence our conclusion of high nitrate aerosol concentration in the UTLS.

As shown in Table 4, for the surface layer, simulated nitrate concentration over the TP/SASM region decreases by $46.8 \%$ (from 0.94 to $0.50 \mu \mathrm{g} \mathrm{m}^{-3}$ ) with a $50 \%$ reduction in anthropogenic $\mathrm{NO}_{x}$ emissions in Asia, and it decreases by $22.3 \%$ (from 0.94 to $0.73 \mu \mathrm{g} \mathrm{m}^{-3}$ ) when anthropogenic $\mathrm{NH}_{3}$ emissions are reduced by the same percentage, indicating that surface-layer nitrate aerosol is more sensitive to anthropogenic emissions of $\mathrm{NO}_{x}$ than to those of $\mathrm{NH}_{3}$. Relative to the baseline simulation, simulated nitrate concentrations at 200 and $100 \mathrm{hPa}$ decrease, respectively, by $49.0 \%$ (from $7.57 \times 10^{-2}$ to $3.86 \times 10^{-2} \mu \mathrm{g} \mathrm{m}{ }^{-3}$ ) and $17.7 \%$ (from $6.90 \times 10^{-2}$ to $5.68 \times 10^{-2} \mu \mathrm{g} \mathrm{m}^{-3}$ ) with a $50 \%$ reduction in $\mathrm{NH}_{3}$ emissions, whereas only by $2.1 \%$ (from $7.57 \times 10^{-2}$ to $7.41 \times 10^{-2} \mu \mathrm{g} \mathrm{m}^{-3}$ ) and $1.3 \%$ (from $6.90 \times 10^{-2}$ to $6.81 \times 10^{-2} \mu \mathrm{g} \mathrm{m}^{-3}$ ) with a $50 \%$ reduction in $\mathrm{NO}_{x}$ emissions. Over the studied region, the role of $\mathrm{NH}_{3}$ in the sulfate-nitrate-ammonium aerosol system can be quantified by the gas ratio of $\mathrm{GR}=\frac{\text { free ammonia }}{\text { total nitrate }}=\frac{\mathrm{TA}-2 \times \mathrm{TS}}{\mathrm{TN}}$ (Ansari and Pandis, 1998), where $\mathrm{TA}=\mathrm{NH}_{3}+\mathrm{NH}_{4}^{+}, \mathrm{TS}=\mathrm{SO}_{4}^{2-}$, and $\mathrm{TN}=\mathrm{HNO}_{3}+\mathrm{NO}_{3}^{-}$. Over the TP/SASM region, the GR is generally positive both at the surface and in the UTLS, especially over $20-40^{\circ} \mathrm{N}$ where deep convection exits (Fig. 11), indicating that free ammonia is available to react with nitrate (Seinfeld and Pandis, 2006). However, the GR is generally less than 1.0 above $400 \mathrm{hPa}$ in summer over the TP/SASM region, which indicates that nitrate concentrations are most sensitive to changes in $\mathrm{NH}_{3}$ and explains the small sensitivity of nitrate aerosol to $\mathrm{NO}_{x}$ emissions in the UTLS.

In the sensitivity study with emissions of $\mathrm{NO}_{x}, \mathrm{NH}_{3}$, and $\mathrm{SO}_{2}$ in Asia changed simultaneously, simulated surfacelayer concentrations of $\mathrm{SO}_{4}^{2-}, \mathrm{NO}_{3}^{-}$, and $\mathrm{NH}_{4}^{+}$have $\mathrm{NMBs}$ 


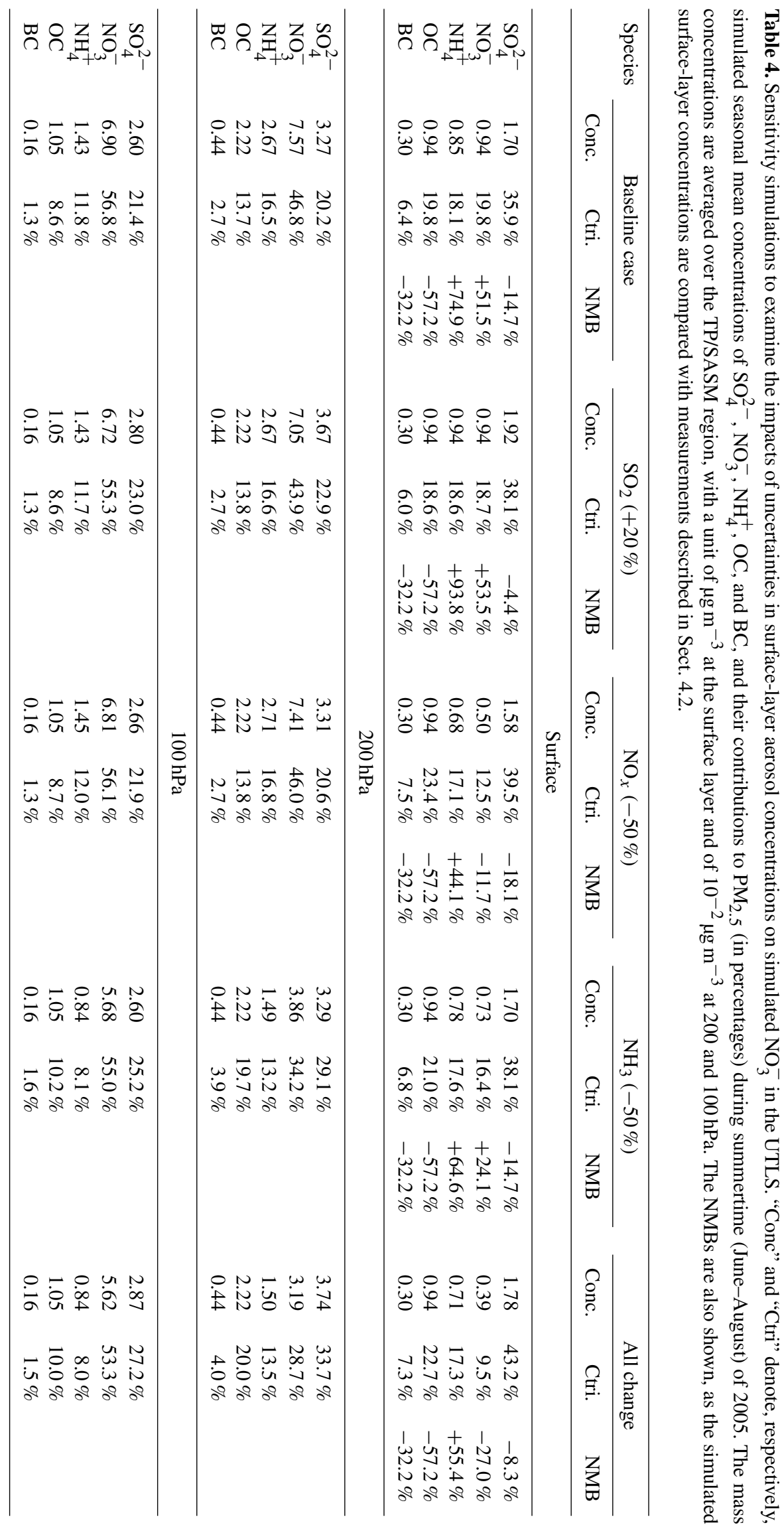



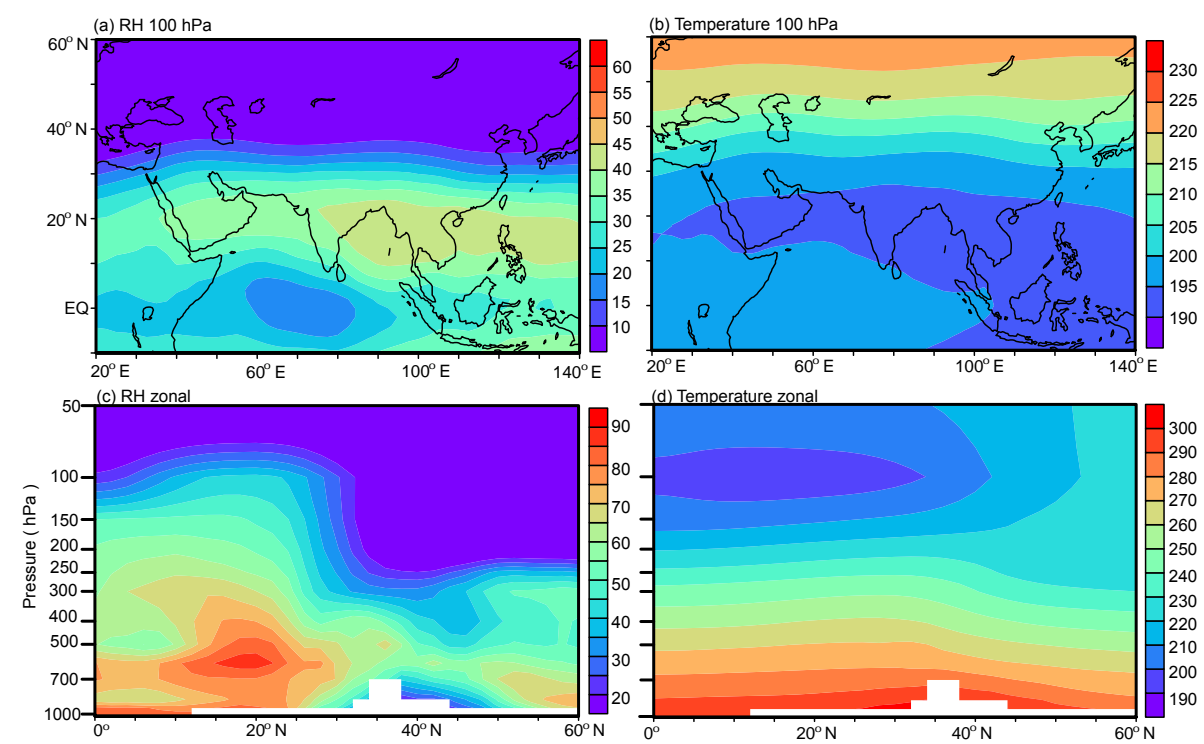

Figure 13. (a, b) Distributions of RH (\%) and temperature (K) at $100 \mathrm{hPa}$. (c, d) The latitude-altitude cross sections of RH (\%) and temperature $(\mathrm{K})$ averaged over $70-105^{\circ} \mathrm{E}$. RH and temperature are from the GEOS5 assimilated meteorological fields, and all the values are the averages over June-August of year 2005.

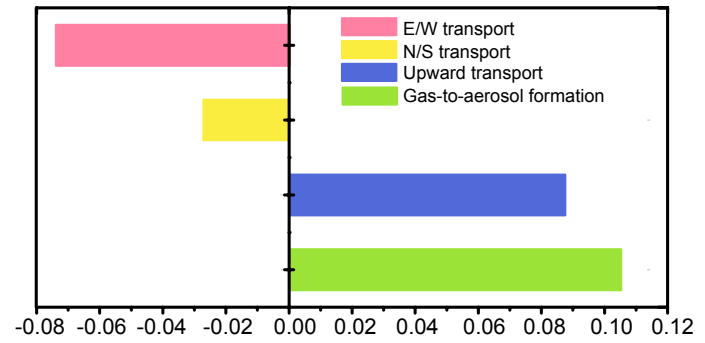

Figure 14. Mass budget for nitrate aerosol within the selected box of $70-105^{\circ} \mathrm{E}, 10-40^{\circ} \mathrm{N}, 8-16 \mathrm{~km}$. E/W transport indicates net mass flux through the east and west lateral boundaries, N/S transport indicates net mass flux through the north and south lateral boundaries, and upward transport is the net mass flux through the top and bottom sides of the box. The mass flux is positive if it increases nitrate mass within the box. Unit of fluxes is $\mathrm{Tg}_{\text {season }}{ }^{-1}$. All the values are the averages over June-August of 2005.

of $-8.3,-27.0$, and $+55.4 \%$, respectively, which are all improved compared to those in the standard simulation. Even though nitrate aerosol is now underestimated at the surface, it still accounts for $53.3 \%$ of the $\mathrm{PM}_{2.5}$ concentration at $100 \mathrm{hPa}$ over the TP/SASM region in summer.

It should be noted that the concentrations of $\mathrm{OC}$ and $\mathrm{BC}$ are also underestimated, with NMBs of -57.2 and $-32.2 \%$, respectively, in summer (Sect. 4.2). We have done a simple calculation with the concentrations of $\mathrm{OC}$ and $\mathrm{BC}$ in the UTLS multiplied by 2.3 and 1.5 , respectively, and nitrate is still the most dominant aerosol species in summertime in the UTLS over the TP/SASM region (not shown in Table 4).
Therefore the uncertainties in surface aerosol concentrations do not compromise the conclusion of this study.

\section{Conclusions}

In this work we simulate nitrate aerosol and its contribution to aerosol concentrations in the UTLS over the TP/SASM region $\left(70-105^{\circ} \mathrm{E}, 10-40^{\circ} \mathrm{N}\right)$ for summertime of year 2005 , using the global chemical transport model GEOS-Chem driven by the assimilated meteorological fields.

Simulated $\mathrm{HNO}_{3}$ and $\mathrm{O}_{3}$ are evaluated to show the model's ability to simulate the $\mathrm{NO}_{x}-\mathrm{O}_{3}-\mathrm{HNO}_{3}$ cycle over the studied region. In the UTLS, both the horizontal and vertical distributions of simulated $\mathrm{HNO}_{3}$ and $\mathrm{O}_{3}$ agree well with the MLS observations. At $100 \mathrm{hPa}$, simulated seasonal mean $\mathrm{HNO}_{3}$ and $\mathrm{O}_{3}$ mixing ratios show NMBs of +11.1 and $+3.5 \%$, respectively, over the TP/SASM region $\left(70-105^{\circ} \mathrm{E}\right.$, $10-40^{\circ} \mathrm{N}$ ) in summer of year 2005 , and the model biases lie within the confidence range of the MLS instruments. Both simulated and observed $\mathrm{O}_{3}$ concentrations show relatively low values of less than $200 \mathrm{ppbv}$ at $100 \mathrm{hPa}$ over the TP/SASM region.

Averaged over the TP/SASM region, the surface-layer concentrations of $\mathrm{SO}_{4}^{2-}, \mathrm{NO}_{3}^{-}, \mathrm{NH}_{4}^{+}, \mathrm{BC}$, and $\mathrm{OC}$ are simulated to be $1.70,0.94,0.85,0.30$, and $0.94 \mu \mathrm{g} \mathrm{m}^{-3}$, respectively. Nitrate aerosol is simulated to be of secondary importance near the surface over the region of our interest. Comparisons of simulated aerosol concentrations with groundbased observations show that simulated summertime concentrations of $\mathrm{SO}_{4}^{2-}, \mathrm{NO}_{3}^{-}, \mathrm{NH}_{4}^{+}, \mathrm{OC}$, and $\mathrm{BC}$ have $\mathrm{NMBs}$ of $-14.7,+51.5,+74.9,-57.2$, and $-32.2 \%$, respectively. 
Note that the measurements of $\mathrm{NO}_{3}^{-}$and $\mathrm{NH}_{4}^{+}$are quite limited in terms of the number of samples.

Model results show elevated concentrations of $\mathrm{SO}_{4}^{2-}$, $\mathrm{NO}_{3}^{-}, \mathrm{NH}_{4}^{+}, \mathrm{OC}, \mathrm{BC}$, and $\mathrm{PM}_{2.5}$ in the UTLS over the TP/SASM region throughout the summer. $\mathrm{NO}_{3}^{-}$is simulated to be the most dominant aerosol species in the UTLS of the TP/SASM region. Accounting for all aerosol species, the GEOS-Chem model reproduces the magnitude of aerosol extinctions above $10 \mathrm{~km}$ well, as model results are compared with the SAGE II measurements. The discrepancies between the simulated and observed aerosol extinction coefficient are within $8 \%$ in the UTLS (averaged over $14-16 \mathrm{~km}$ ). Simulated vertical profiles of aerosol extinction coefficients with and without nitrate aerosol show large discrepancies from $6 \mathrm{~km}$ to tropopause, indicating the important role of nitrate in the aerosol layer in the UTLS over the TP/SASM region.

The contribution of $\mathrm{NO}_{3}^{-}$to aerosols in the TP/SASM region is quantified by $C_{\text {NIT }}$ (the ratio of nitrate concentration to $\mathrm{PM}_{2.5}$ concentration). Over the TP/SASM region, the $C_{\text {NIT }}$ values in summer are 5-35\% at the surface, $25-50 \%$ at $200 \mathrm{hPa}$, and could exceed $60 \%$ at $100 \mathrm{hPa}$. The mechanisms for the accumulation of nitrate in the UTLS over the TP/SASM region include vertical transport and the gas-toaerosol conversion of $\mathrm{HNO}_{3}$ to form nitrate. Such gas-toaerosol conversion occurs during upward transport and in the UTLS. The high relative humidity and low temperature associated with the deep convection over the TP/SASM region are favorable for nitrate formation.

Results from the present study indicate that nitrate is an important aerosol species in the UTLS over the TP/SASM region. Considering the scarce measurements of nitrate in the UTLS and the model uncertainties, more observational and modeling studies are needed to further explore the aerosol composition in the Asian tropopause aerosol layer. Further simulations of nitrate aerosol in the UTLS also need to account for NAT formation at low temperatures (Kirner et al., 2011) and the roles of natural aerosols, including the transport of mineral dust and sea salt to the UTLS as well as nitrate formation on these natural particles (Ma et al., 2003).

\section{The Supplement related to this article is available online at doi:10.5194/acp-16-6641-2016-supplement.}

Acknowledgements. This work was supported by the $\mathrm{Na}-$ tional Basic Research Program of China (973 program, grant no. 2014CB441202), the Strategic Priority Research Program of the Chinese Academy of Sciences (grant no. XDA05100503), and the National Natural Science Foundation of China under grants 41021004, 41475137, and 91544219. We gratefully acknowledge NASA, United States, for providing the MLS and SAGE II data on their website.

Edited by: X. Xu

\section{References}

Alexander, B., Park, R. J., Jacob, D. J., Li, Q., Yantosca, R. M., Savarino, J., Lee, C., and Thiemens, M.: Sulfate formation in sea-salt aerosols: Constraints from oxygen isotopes, J. Geophys. Res., 110, D10307, doi:10.1029/2004JD005659, 2005.

Ansari, A. S. and Pandis, S. N.: Response of Inorganic PM to Precursor Concentrations, Environ. Sci. Technol., 32, 2706-2714, 1998.

Arimoto, R., Duce, R., Savoie, D., Prospero, J., Talbot, R., Cullen, J., Tomza, U., Lewis, N., and Ray, B.: Relationships among aerosol constituents from Asia and the North Pacific during PEM-West A, J. Geophys. Res., 101, 2011-2023, 1996.

Bian, J., Yan, R., and Chen, H.: Tropospheric Pollutant Transport to the Stratosphere by Asian Summer Monsoon, Chin. J. Atmos. Sci., 35, 897-902, 2011a.

Bian, J., Yan, R., Chen, H., Lü, D., and MASSIE, S. T.: Formation of the Summertime Ozone Valley over the Tibetan Plateau: The Asian Summer Monsoon and Air Column Variations, Adv. Atmos. Sci., 28, 1318-1325, 2011 b.

Bian, J., Pan, L. L., Paulik, L., Vömel, H., Chen, H., and Lü, D.: In situ water vapor and ozone measurements in Lhasa and Kunming during the Asian summer monsoon, Geophys. Res. Lett., 39, L19808, doi:10.1029/2012GL052996, 2012.

Bourgeois, Q., Bey, I., and Stier, P.: A permanent aerosol layer at the tropical tropopause layer driven by the intertropical convergence zone, Atmos. Chem. Phys. Discuss., 12, 2863-2889, doi:10.5194/acpd-12-2863-2012, 2012.

Bouwman, A., Lee, D., Asman, W., Dentener, F., Van Der Hoek, K., and Olivier, J.: A global high-resolution emission inventory for ammonia, Global Biogeochem. Cy., 11, 561-587, 1997.

Brewer, A. W.: Evidence for a world circulation provided by the measurements of helium and water vapour distribution in the stratosphere, Q. J. Roy. Meteorol. Soc., 75, 351-363, 1949.

Carslaw, K., Wirth, M., Tsias, A., Luo, B., Dörnbrack, A., Leutbecher, M., Volkert, H., Renger, W., Bacmeister, J., and Peter, T.: Particle microphysics and chemistry in remotely observed mountain polar stratospheric clouds, J. Geophys. Res., 103, 57855796, 1998.

Chatterjee, A., Adak, A., Singh, A. K., Srivastava, M. K., Ghosh, S. K., Tiwari, S., Devara, P. C., and Raha, S.: Aerosol chemistry over a high altitude station at northeastern Himalayas, India, PloS One, 5, e11122, doi:10.1371/journal.pone.0011122, 2010.

Chen, H., Bian, J., and Lü, D.: Advances and prospects in the study of stratosphere-troposphere exchange, Chinese J. Atmos. Sci., 30, 813-820, 2006.

Chin, M., Ginoux, P., Kinne, S., Torres, O., Holben, B., Duncan, B. N., Martin, R. V., Logan, J. A., Higurashi, A., and Nakajima, T.: Tropospheric aerosol optical thickness from the GOCART model and comparisons with satellite and sunphotometer measurements, J. Atmos. Sci., 59, 461-483, 2002.

Chu, W., McCormick, M., Lenoble, J., Brogniez, C., and Pruvost, P.: SAGE II inversion algorithm, J. Geophys. Res., 94, 8339-8351, 1989.

Chung, S. H. and Seinfeld, J. H.: Global distribution and climate forcing of carbonaceous aerosols, J. Geophys. Res., 107, 4407, doi:10.1029/2001JD001397, 2002.

Collins, W. J., Stevenson, D. S., Johnson, C. E., and Derwent, R. G.: The European regional ozone distribution and its links with 
the global scale for the years 1992 and 2015, Atmos. Environ., 34, 255-267, 2000.

Considine, D. B., Rosenfield, J. E., and Fleming, E. L.: An interactive model study of the influence of the Mount Pinatubo aerosol on stratospheric methane and water trends, J. Geophys. Res., 106, 27711-27727, doi:10.1029/2001jd000331, 2001.

Considine, D. B., Logan, J. A., and Olsen, M. A.: Evaluation of near-tropopause ozone distributions in the Global Modeling Initiative combined stratosphere/troposphere model with ozonesonde data, Atmos. Chem. Phys., 8, 2365-2385, doi:10.5194/acp-8-2365-2008, 2008.

Cooke, W. F., Liousse, C., Cachier, H., and Feichter, J.: Construction of a $1^{\circ} \times 1^{\circ}$ fossil fuel emission data set for carbonaceous aerosol and implementation and radiative impact in the ECHAM4 model, J. Geophys. Res., 104, 22137-22162, 1999.

Datta, A., Sharma, S., Harit, R., Kumar, V., Mandal, T., and Pathak, H.: Ammonia emission from subtropical crop land area in India, Asia-Pac. J. Atmos. Sci., 48, 275-281, 2012.

Dawson, J. P., Adams, P. J., and Pandis, S. N.: Sensitivity of $\mathrm{PM}_{2.5}$ to climate in the Eastern US: a modeling case study, Atmos. Chem. Phys., 7, 4295-4309, doi:10.5194/acp-7-4295-2007, 2007.

Decesari, S., Facchini, M. C., Carbone, C., Giulianelli, L., Rinaldi, M., Finessi, E., Fuzzi, S., Marinoni, A., Cristofanelli, P., Duchi, R., Bonasoni, P., Vuillermoz, E., Cozic, J., Jaffrezo, J. L., and Laj, P.: Chemical composition of $\mathrm{PM}_{10}$ and $\mathrm{PM}_{1}$ at the high-altitude Himalayan station Nepal Climate ObservatoryPyramid (NCO-P) (5079 ma.s.1.), Atmos. Chem. Phys., 10, 4583-4596, doi:10.5194/acp-10-4583-2010, 2010.

Dobson, G. M. B.: Origin and distribution of the polyatomic molecules in the atmosphere, P. Roy. Soc. Lond. A, 236, 187193, doi:10.1098/rspa.1956.0127,

Drury, E., Jacob, D. J., Spurr, R. J., Wang, J., Shinozuka, Y., Anderson, B. E., Clarke, A. D., Dibb, J., McNaughton, C., and Weber, R.: Synthesis of satellite (MODIS), aircraft (ICARTT), and surface (IMPROVE, EPA-AQS, AERONET) aerosol observations over eastern North America to improve MODIS aerosol retrievals and constrain surface aerosol concentrations and sources, J. Geophys. Res., 115, D14204, doi:10.1029/2009JD012629, 2010.

Duncan, B. N., Strahan, S. E., Yoshida, Y., Steenrod, S. D., and Livesey, N.: Model study of the cross-tropopause transport of biomass burning pollution, Atmos. Chem. Phys., 7, 3713-3736, doi:10.5194/acp-7-3713-2007, 2007.

Evans, M., and Jacob, D. J.: Impact of new laboratory studies of $\mathrm{N}_{2} \mathrm{O}_{5}$ hydrolysis on global model budgets of tropospheric nitrogen oxides, ozone, and OH, Geophys. Res. Lett., 32, L09813, doi:10.1029/2005GL022469, 2005.

Fadnavis, S., Semeniuk, K., Pozzoli, L., Schultz, M. G., Ghude, S. D., Das, S., and Kakatkar, R.: Transport of aerosols into the UTLS and their impact on the Asian monsoon region as seen in a global model simulation, Atmos. Chem. Phys., 13, 8771-8786, doi:10.5194/acp-13-8771-2013, 2013.

Fadnavis, S., Semeniuk, K., Schultz, M. G., Kiefer, M., Mahajan, A., Pozzoli, L., and Sonbawane, S.: Transport pathways of peroxyacetyl nitrate in the upper troposphere and lower stratosphere from different monsoon systems during the summer monsoon season, Atmos. Chem. Phys., 15, 11477-11499, doi:10.5194/acp-15-11477-2015, 2015.
Fairlie, T. D., Jacob, D. J., and Park, R. J.: The impact of transpacific transport of mineral dust in the United States, Atmos. Environ., 41, 1251-1266, 2007.

Fisher, J. A., Jacob, D. J., Wang, Q., Bahreini, R., Carouge, C. C., Cubison, M. J., Dibb, J. E., Diehl, T., Jimenez, J. L., and Leibensperger, E. M.: Sources, distribution, and acidity of sulfate-ammonium aerosol in the Arctic in winter-spring, Atmos. Environ., 45, 7301-7318, 2011.

Fountoukis, C. and Nenes, A.: ISORROPIA II: a computationally efficient thermodynamic equilibrium model for $\mathrm{K}^{+}$ $\mathrm{Ca}_{2}^{+}-\mathrm{Mg}_{2}^{+}-\mathrm{NH}_{4}^{+}-\mathrm{Na}^{+}-\mathrm{SO}_{4}^{2-}-\mathrm{NO}_{3}-\mathrm{Cl}-\mathrm{H}_{2} \mathrm{O}$ aerosols, Atmos. Chem. Phys., 7, 4639-4659, doi:10.5194/acp-7-4639-2007, 2007.

Froyd, K. D., Murphy, D. M., Sanford, T. J., Thomson, D. S., Wilson, J. C., Pfister, L., and Lait, L.: Aerosol composition of the tropical upper troposphere, Atmos. Chem. Phys., 9, 4363-4385, doi:10.5194/acp-9-4363-2009, 2009.

Fu, R., Hu, Y., Wright, J. S., Jiang, J. H., Dickinson, R. E., Chen, M., Filipiak, M., Read, W. G., Waters, J. W., and Wu, D. L.: Short circuit of water vapor and polluted air to the global stratosphere by convective transport over the Tibetan Plateau, P. Natl. Acad. Sci. USA, 103, 5664-5669, 2006.

Fu, T.-M., Cao, J. J., Zhang, X. Y., Lee, S. C., Zhang, Q., Han, Y. M., Qu, W. J., Han, Z., Zhang, R., Wang, Y. X., Chen, D., and Henze, D. K.: Carbonaceous aerosols in China: top-down constraints on primary sources and estimation of secondary contribution, Atmos. Chem. Phys., 12, 2725-2746, doi:10.5194/acp12-2725-2012, 2012.

George, S. K. and Nair, P. R.: Aerosol mass loading over the marine environment of Arabian Sea during ICARB: Sea-salt and nonsea-salt components, J. Earth Syst. Sci., 117, 333-344, 2008.

George, S. K., Nair, P. R., Parameswaran, K., Jacob, S., and Abraham, A.: Seasonal trends in chemical composition of aerosols at a tropical coastal site of India, J. Geophys. Res., 113, D16209, doi:10.1029/2007JD009507, 2008.

Gettelman, A., Kinnison, D. E., Dunkerton, T. J., and Brasseur, G. P.: Impact of monsoon circulations on the upper troposphere and lower stratosphere, J. Geophys. Res., 109, D22101, doi:10.1029/2004JD004878, 2004.

Guenther, A., Karl, T., Harley, P., Wiedinmyer, C., Palmer, P. I., and Geron, C.: Estimates of global terrestrial isoprene emissions using MEGAN (Model of Emissions of Gases and Aerosols from Nature), Atmos. Chem. Phys., 6, 3181-3210, doi:10.5194/acp-63181-2006, 2006.

Hack, J. J.: Parameterization of moist convection in the National Center for Atmospheric Research community climate model (CCM2), J. Geophys. Res., 99, 5551-5568, doi:10.1029/93jd03478, 1994.

He, Q. S., Li, C. C., Ma, J. Z., Wang, H. Q., Yan, X. L., Lu, J., Liang, Z. R., and Qi, G. M.: Lidar-observed enhancement of aerosols in the upper troposphere and lower stratosphere over the Tibetan Plateau induced by the Nabro volcano eruption, Atmos. Chem. Phys., 14, 11687-11696, doi:10.5194/acp-14-11687-2014, 2014.

Hofmann, D., Rosen, J., Harder, J., and Hereford, J.: Balloon-borne measurements of aerosol, condensation nuclei, and cloud particles in the stratosphere at McMurdo Station, Antarctica, during the spring of 1987, J. Geophys. Res., 94, 11253-11269, doi:10.1029/JD094iD09p11253, 1989. 
Huang, C., Chen, C. H., Li, L., Cheng, Z., Wang, H. L., Huang, H. Y., Streets, D. G., Wang, Y. J., Zhang, G. F., and Chen, Y. R.: Emission inventory of anthropogenic air pollutants and VOC species in the Yangtze River Delta region, China, Atmos. Chem. Phys., 11, 4105-4120, doi:10.5194/acp-11-4105-2011, 2011.

Huang, X., Song, Y., Li, M., Li, J., Huo, Q., Cai, X., Zhu, T., Hu, M., and Zhang, H.: A high-resolution ammonia emission inventory in China, Global Biogeochem. Cy., 26, GB1030, doi:10.1029/2011GB004161, 2012.

Jacob, D. J.: Heterogeneous chemistry and tropospheric ozone, Atmos. Environ., 34, 2131-2159, 2000.

Jaeglé, L., Quinn, P., Bates, T., Alexander, B., and Lin, J.-T.: Global distribution of sea salt aerosols: new constraints from in situ and remote sensing observations, Atmos. Chem. Phys., 11, 31373157, doi:10.5194/acp-11-3137-2011, 2011.

Jeong, J. I. and Park, R. J.: Effects of the meteorological variability on regional air quality in East Asia, Atmos. Environ., 69, 46-55, 2013

Jiang, H., Liao, H., Pye, H. O. T., Wu, S., Mickley, L. J., Seinfeld, J. H., and Zhang, X. Y.: Projected effect of 2000-2050 changes in climate and emissions on aerosol levels in China and associated transboundary transport, Atmos. Chem. Phys., 13, 7937-7960, doi:10.5194/acp-13-7937-2013, 2013.

Kar, J., Bremer, H., Drummond, J. R., Rochon, Y. J., Jones, D., Nichitiu, F., Zou, J., Liu, J., Gille, J. C., and Edwards, D. P.: Evidence of vertical transport of carbon monoxide from Measurements of Pollution in the Troposphere (MOPITT), Geophys. Res. Lett., 31, L23105, doi:10.1029/2004GL021128, 2004.

Kim, J., Song, C. H., Ghim, Y., Won, J., Yoon, S., Carmichael, G., and Woo, J. H.: An investigation on $\mathrm{NH}_{3}$ emissions and particulate $\mathrm{NH}_{4}^{+}-\mathrm{NO}_{3}^{-}$formation in East Asia, Atmos. Environ., 40, 2139-2150, 2006.

Kim, Y.-S., Shibata, T., Iwasaka, Y., Shi, G., Zhou, X., Tamura, K., and Ohashi, T.: Enhancement of aerosols near the cold tropopause in summer over Tibetan Plateau: lidar and balloonborne measurements in 1999 at Lhasa, Tibet, China, in: Lidar Remote Sensing for Industry and Environment Monitoring III, edited by: Singh U. N., Itabe, T., and Liu, Z., Proceedings of SPIE, Hangzhou, China, 4893, 496-503, 2003.

Kirner, O., Ruhnke, R., Buchholz-Dietsch, J., Jöckel, P., Brühl, C., and Steil, B.: Simulation of polar stratospheric clouds in the chemistry-climate-model EMAC via the submodel PSC, Geosci. Model Dev., 4, 169-182, doi:10.5194/gmd-4-169-2011, 2011.

Kulkarni, P. and Ramachandran, S.: Comparison of aerosol extinction between lidar and SAGE II over Gadanki, a tropical station in India, Ann. Geophys., 33, 351-362, doi:10.5194/angeo-33351-2015, 2015.

Lau, K. M., Kim, M. K., and Kim, K. M.: Asian summer monsoon anomalies induced by aerosol direct forcing: the role of the Tibetan Plateau, Clim. Dynam., 26, 855-864, doi:10.1007/s00382006-0114-z, 2006.

Lawrence, M. G., and Lelieveld, J.: Atmospheric pollutant outflow from southern Asia: a review, Atmos. Chem. Phys., 10, 1101711096, doi:10.5194/acp-10-11017-2010, 2010.

Lelieveld, J., Crutzen, P. J., Ramanathan, V., Andreae, M. O., Brenninkmeijer, C. A. M., Campos, T., Cass, G. R., Dickerson, R. R., Fischer, H., de Gouw, J. A., Hansel, A., Jefferson, A., Kley, D., de Laat, A. T. J., Lal, S., Lawrence, M. G., Lobert, J. M., MayolBracero, O. L., Mitra, A. P., Novakov, T., Oltmans, S. J., Prather,
K. A., Reiner, T., Rodhe, H., Scheeren, H. A., Sikka, D., and Williams, J.: The Indian Ocean Experiment: Widespread air pollution from South and Southeast Asia, Science, 291, 1031-1036, doi:10.1126/science.1057103, 2001.

Li, Q., Jiang, J. H., Wu, D. L., Read, W. G., Livesey, N. J., Waters, J. W., Zhang, Y., Wang, B., Filipiak, M. J., and Davis, C. P.: Convective outflow of South Asian pollution: A global CTM simulation compared with EOS MLS observations, Geophys. Res. Lett., 32, L14826, doi:10.1029/2005GL022762, 2005.

Liao, H. and Seinfeld, J. H.: Global impacts of gas-phase chemistryaerosol interactions on direct radiative forcing by anthropogenic aerosols and ozone, J. Geophys. Res., 110, D18208, doi:10.1029/2005JD005907, 2005.

Liao, H., Adams, P. J., Chung, S. H., Seinfeld, J. H., Mickley, L. J., and Jacob, D. J.: Interactions between tropospheric chemistry and aerosols in a unified general circulation model, J. Geophys. Res., 108, 4001, doi:10.1029/2001JD001260, 2003.

Liao, H., Zhang, Y., Chen, W.-T., Raes, F., and Seinfeld, J. H.: Effect of chemistry-aerosol-climate coupling on predictions of future climate and future levels of tropospheric ozone and aerosols, J. Geophys. Res., 114, D10306, doi:10.1029/2008JD010984, 2009.

Liu, H., Jacob, D. J., Bey, I., and Yantosca, R. M.: Constraints from ${ }^{210} \mathrm{~Pb}$ and ${ }^{7} \mathrm{Be}$ on wet deposition and transport in a global threedimensional chemical tracer model driven by assimilated meteorological fields, J. Geophys. Res., 106, 12109-12128, 2001.

Liu, X., Penner, J. E., and Wang, M.: Influence of anthropogenic sulfate and black carbon on upper tropospheric clouds in the NCAR CAM3 model coupled to the IMPACT global aerosol model, J. Geophys. Res., 114, D03204, doi:10.1029/2008JD010492, 2009.

Livesey, N. J., Filipiak, M. J., Froidevaux, L., Read, W. G., Lambert, A., Santee, M. L., Jiang, J. H., Pumphrey, H. C., Waters, J. W., and Cofield, R. E.: Validation of Aura Microwave Limb Sounder $\mathrm{O}_{3}$ and $\mathrm{CO}$ observations in the upper troposphere and lower stratosphere, J. Geophys. Res., 113, D15S02, doi:10.1029/2007JD008805, 2008.

Livesey, N. J., Read, W. G., Wagner, P. A., Froidevaux, L., Lambert, A., Manney, G. L., Pumphrey, H. C., Santee, M. L., Schwartz, M. J., Wang, S., Cofield, R. E., Cuddy, D. T., Fuller, R. A., Jarnot, R. F., Jiang, J. H., and Knosp, B. W.: Earth Observing System (EOS) Microwave Limb Sounder (MLS) Version 3.3 Level 2 data quality and description document, Tech. Rep. JPL D-33509, NASA Jet Propulsion Laboratory, version 3.3x-1.0, 2011.

Lodhi, A., Ghauri, B., Khan, M. R., Rahman, S., and Shafique, S.: Particulate matter $\left(\mathrm{PM}_{2.5}\right)$ concentration and source apportionment in Lahore, J. Brazil. Chem. Soc., 20, 1811-1820, 2009.

Lou, S., Liao, H., and Zhu, B.: Impacts of aerosols on surface-layer ozone concentrations in China through heterogeneous reactions and changes in photolysis rates, Atmos. Environ., 85, 123-138, 2014.

Luo, Y., Zhang, R., Qian, W., Luo, Z., and Hu, X.: Inter-comparison of deep convection over the Tibetan Plateau-Asian monsoon region and subtropical North America in boreal summer using CloudSat/CALIPSO data, J. Climate, 24, 2164-2177, 2011.

Ma, J., Tang, J., Li, S.-M., and Jacobson, M. Z.: Size distributions of ionic aerosols measured at Waliguan Observatory: Implication for nitrate gas-to-particle transfer processes in the free troposphere, J. Geophys. Res., 108, 4541, doi:10.1029/2002jd003356, 2003. 
Martin, R. V., Jacob, D. J., Yantosca, R. M., Chin, M., and Ginoux, P.: Global and regional decreases in tropospheric oxidants from photochemical effects of aerosols, J. Geophys. Res., 108, 4097, doi:10.1029/2002JD002622, 2003.

Martin, R. V., Sauvage, B., Folkins, I., Sioris, C. E., Boone, C., Bernath, P., and Ziemke, J.: Space-based constraints on the production of nitric oxide by lightning, J. Geophys. Res., 112, D09309, doi:10.1029/2006JD007831, 2007.

McCormick, M. P.: SAGE II: an overview, Adv. Space Res., 7, 219 226, 1987.

McLinden, C., Olsen, S., Hannegan, B., Wild, O., Prather, M., and Sundet, J.: Stratospheric ozone in 3-D models: A simple chemistry and the cross-tropopause flux, J. Geophys. Res., 105, 14653-14665, doi:10.1029/2000JD900124, 2000.

Mickley, L. J., Murti, P., Jacob, D. J., Logan, J. A., Koch, D., and Rind, D.: Radiative forcing from tropospheric ozone calculated with a unified chemistry-climate model, J. Geophys. Res., 104, 30153-30172, 1999.

$\mathrm{Mu}, \mathrm{Q}$. and Liao, H.: Simulation of the interannual variations of aerosols in China: role of variations in meteorological parameters, Atmos. Chem. Phys., 14, 9597-9612, doi:10.5194/acp-149597-2014, 2014.

Murray, L. T., Jacob, D. J., Logan, J. A., Hudman, R. C., and Koshak, W. J.: Optimized regional and interannual variability of lightning in a global chemical transport model constrained by LIS/OTD satellite data, J. Geophys. Res., 117, D20307, doi:10.1029/2012JD017934, 2012.

Nakamura, T., Matsumoto, K., and Uematsu, M.: Chemical characteristics of aerosols transported from Asia to the East China Sea: an evaluation of anthropogenic combined nitrogen deposition in autumn, Atmos. Environ., 39, 1749-1758, 2005.

Oberbeck, V. R., Livingston, J. M., Russell, P. B., Pueschel, R. F., Rosen, J. N., Osborn, M. T., Kritz, M. A., Snetsinger, K. G., and Ferry, G. V.: SAGE II aerosol validation: Selected altitude measurements, including particle micromeasurements, J. Geophys. Res., 94, 8367-8380, doi:10.1029/JD094iD06p08367, 1989.

Park, M., Randel, W. J., Kinnison, D. E., Garcia, R. R., and Choi, W.: Seasonal variation of methane, water vapor, and nitrogen oxides near the tropopause: Satellite observations and model simulations, J. Geophys. Res., 109, D03302, doi:10.1029/2003JD003706, 2004.

Park, M., Randel, W. J., Gettelman, A., Massie, S. T., and Jiang, J. H.: Transport above the Asian summer monsoon anticyclone inferred from Aura Microwave Limb Sounder tracers, J. Geophys. Res., 112, D16309, doi:10.1029/2006JD008294, 2007.

Park, M., Randel, W. J., Emmons, L. K., Bernath, P. F., Walker, K. A., and Boone, C. D.: Chemical isolation in the Asian monsoon anticyclone observed in Atmospheric Chemistry Experiment (ACE-FTS) data, Atmos. Chem. Phys., 8, 757-764, doi:10.5194/acp-8-757-2008, 2008.

Park, M., Randel, W. J., Emmons, L. K., and Livesey, N. J.: Transport pathways of carbon monoxide in the Asian summer monsoon diagnosed from Model of Ozone and Related Tracers (MOZART), J. Geophys. Res., 114, D08303, doi:10.1029/2008JD010621, 2009.

Park, R. J., Jacob, D. J., Chin, M., and Martin, R. V.: Sources of carbonaceous aerosols over the United States and implications for natural visibility, J. Geophys. Res., 108, 4355, doi:10.1029/2002JD003190, 2003.
Park, R. J., Jacob, D. J., Field, B. D., Yantosca, R. M., and Chin, M.: Natural and transboundary pollution influences on sulfate-nitrate-ammonium aerosols in the United States: Implications for policy, J. Geophys. Res., 109, D15204, doi:10.1029/2003JD004473, 2004.

Pitari, G., Aquila, V., Kravitz, B., Robock, A., Watanabe, S., Cionni, I., Luca, N. D., Genova, G. D., Mancini, E., and Tilmes, S.: Stratospheric ozone response to sulfate geoengineering: Results from the Geoengineering Model Intercomparison Project (GeoMIP), J. Geophys. Res., 119, 2629-2653, doi:10.1002/2013JD020566, 2014.

Pitari, G., Iachetti, D., Genova, G. D., De Luca, N., Søvde, O., Hodnebrog, Ø., Lee, D. S., and Lim, L. L.: Impact of coupled $\mathrm{NO}_{x}$ /aerosol aircraft emissions on ozone photochemistry and radiative forcing, Atmosphere, 6, 751-782, doi:10.3390/atmos6060751, 2015.

Popp, P. J., Marcy, T. P., Jensen, E. J., Kärcher, B., Fahey, D. W., Gao, R. S., Thompson, T. L., Rosenlof, K. H., Richard, E. C., Herman, R. L., Weinstock, E. M., Smith, J. B., May, R. D., Vömel, H., Wilson, J. C., Heymsfield, A. J., Mahoney, M. J., and Thompson, A. M.: The observation of nitric acid-containing particles in the tropical lower stratosphere, Atmos. Chem. Phys., 6, 601-611, doi:10.5194/acp-6-601-2006, 2006.

Pye, H., Liao, H., Wu, S., Mickley, L. J., Jacob, D. J., Henze, D. K., and Seinfeld, J.: Effect of changes in climate and emissions on future sulfate-nitrate-ammonium aerosol levels in the United States, J. Geophys. Res., 114, D01205, doi:10.1029/2008JD010701, 2009.

Qie, X., Wu, X., Yuan, T., Bian, J., and Lü, D.: Comprehensive Pattern of Deep Convective Systems over the Tibetan Plateau-South Asian Monsoon Region Based on TRMM Data, J. Climate, 27, 6612-6626, 2014.

Randel, W. J. and Park, M.: Deep convective influence on the Asian summer monsoon anticyclone and associated tracer variability observed with Atmospheric Infrared Sounder (AIRS), J. Geophys. Res., 111, D12314, doi:10.1029/2005JD006490, 2006.

Randel, W. J., Park, M., Emmons, L., Kinnison, D., Bernath, P., Walker, K. A., Boone, C., and Pumphrey, H.: Asian monsoon transport of pollution to the stratosphere, Science, 328, 611-613, 2010.

Rasch, P. J., Tilmes, S., Turco, R. P., Robock, A., Oman, L., Chen, C. C., Stenchikov, G. L., and Garcia, R. R.: An overview of geoengineering of climate using stratospheric sulphate aerosols, Philos. T. Roy. Soc. A, 366, 4007-4037, doi:10.1098/rsta.2008.0131, 2008.

Russell, P. B. and Mccormick, M. P.: SAGE II aerosol data validation and initial data use: An introduction and overview, J. Geophys. Res., 94, 8335-8338, 1989.

Santee, M., Lambert, A., Read, W., Livesey, N., Cofield, R., Cuddy, D., Daffer, W., Drouin, B., Froidevaux, L., and Fuller, R.: Validation of the Aura Microwave Limb Sounder $\mathrm{HNO}_{3}$ measurements, J. Geophys. Res., 112, D24S40, doi:10.1029/2007JD008721, 2007.

Sauvage, B., Martin, R. V., van Donkelaar, A., Liu, X., Chance, K., Jaeglé, L., Palmer, P. I., Wu, S., and Fu, T.-M.: Remote sensed and in situ constraints on processes affecting tropical tropospheric ozone, Atmos. Chem. Phys., 7, 815-838, doi:10.5194/acp-7-815-2007, 2007. 
Seinfeld, J. H. and Pandis, S. N.: Atmospheric chemistry and physics: from air pollution to climate change, 2nd Edn., John Wiley: A Wiley-Interscience Publication Press, New York, 27-482, 2006.

Shrestha, A. B., Wake, C. P., Dibb, J. E., Mayewski, P. A., Whitlow, S. I., Carmichael, G. R., and Ferm, M.: Seasonal variations in aerosol concentrations and compositions in the Nepal Himalaya, Atmos. Environ., 34, 3349-3363, doi:10.1016/s13522310(99)00366-0, 2000.

Škerlak, B., Sprenger, M., and Wernli, H.: A global climatology of stratosphere-troposphere exchange using the ERA-Interim data set from 1979 to 2011, Atmos. Chem. Phys, 14, 913-937, doi:10.5194/acp-14-913-2014, 2014.

Stevenson, D. S., Dentener, F. J., Schultz, M. G., Ellingsen, K., Van Noije, T. P. C., Wild, O., Zeng, G., Amann, M., Atherton, C. S., and Bell, N.: Multimodel ensemble simulations of presentday and near-future tropospheric ozone, J. Geophys. Res., 111, D08301, doi:10.1029/2005JD006338, 2006.

Streets, D. G., Bond, T. C., Carmichael, G. R., Fernandes, S. D., Fu, Q., He, D., Klimont, Z., Nelson, S. M., Tsai, N. Y., and Wang, M. Q.: An inventory of gaseous and primary aerosol emissions in Asia in the year 2000, J. Geophys. Res., 108, 30-31, 2003.

Su, H., Jiang, J. H., Lu, X. H., Penner, J. E., Read, W. G., Massie, S., Schoeberl, M. R., Colarco, P., Livesey, N. J., and Santee, M. L.: Observed Increase of TTL Temperature and Water Vapor in Polluted Clouds over Asia, J. Climate, 24, 2728-2736, doi:10.1175/2010jcli3749.1, 2011.

Talukdar, R. K., Burkholder, J. B., Roberts, J. M., Portmann, R. W., and Ravishankara, A.: Heterogeneous Interaction of $\mathrm{N}_{2} \mathrm{O}_{5}$ with $\mathrm{HCl}$ Doped $\mathrm{H}_{2} \mathrm{SO}_{4}$ under Stratospheric Conditions: $\mathrm{ClNO}_{2}$ and $\mathrm{Cl}_{2}$ Yields, J. Phys. Chem. A, 116, 6003-6014, 2012.

Tang, M. J., Telford, P. J., Pope, F. D., Rkiouak, L., Abraham, N. L., Archibald, A. T., Braesicke, P., Pyle, J. A., McGregor, J., Watson, I. M., Cox, R. A., and Kalberer, M.: Heterogeneous reaction of $\mathrm{N}_{2} \mathrm{O}_{5}$ with airborne $\mathrm{TiO}_{2}$ particles and its implication for stratospheric particle injection, Atmos. Chem. Phys., 14, 6035-6048, doi:10.5194/acp-14-6035-2014, 2014.

Thornton, J. A., Jaeglé, L., and McNeill, V. F.: Assessing known pathways for $\mathrm{HO}_{2}$ loss in aqueous atmospheric aerosols: Regional and global impacts on tropospheric oxidants, J. Geophys. Res., 113, D05303, doi:10.1029/2007JD009236, 2008.

Tobo, Y., Zhang, D., Iwasaka, Y., and Shi, G.: On the mixture of aerosols and ice clouds over the Tibetan Plateau: Results of a balloon flight in the summer of 1999, Geophys. Res. Lett., 34, L23801, doi:10.1029/2007GL031132, 2007.

van der Werf, G. R., Randerson, J. T., Giglio, L., Collatz, G. J., Mu, M., Kasibhatla, P. S., Morton, D. C., DeFries, R. S., Jin, Y., and van Leeuwen, T. T.: Global fire emissions and the contribution of deforestation, savanna, forest, agricultural, and peat fires (19972009), Atmos. Chem. Phys., 10, 11707-11735, doi:10.5194/acp10-11707-2010, 2010.

Vanhellemont, F., Tetard, C., Bourassa, A., Fromm, M., Dodion, J., Fussen, D., Brogniez, C., Degenstein, D., Gilbert, K. L., Turnbull, D. N., Bernath, P., Boone, C., and Walker, K. A.: Aerosol extinction profiles at $525 \mathrm{~nm}$ and $1020 \mathrm{~nm}$ derived from ACE imager data: comparisons with GOMOS, SAGE II, SAGE III, POAM III, and OSIRIS, Atmos. Chem. Phys., 8, 2027-2037, doi:10.5194/acp-8-2027-2008, 2008.
Vernier, J.-P., Pommereau, J.-P., Garnier, A., Pelon, J., Larsen, N., Nielsen, J., Christensen, T., Cairo, F., Thomason, L., and Leblanc, T.: Tropical stratospheric aerosol layer from CALIPSO lidar observations, J. Geophys. Res., 114, D00H10, doi:10.1029/2009JD011946, 2009.

Vernier, J. P., Thomason, L., and Kar, J.: CALIPSO detection of an Asian tropopause aerosol layer, Geophys. Res. Lett., 38, L07804, doi:10.1029/2010GL046614, 2011.

Voigt, C., Schreiner, J., Kohlmann, A., Zink, P., Mauersberger, K., Larsen, N., Deshler, T., Kröger, C., Rosen, J., and Adriani, A.: Nitric acid trihydrate (NAT) in polar stratospheric clouds, Science, 290, 1756-1758, 2000.

Wang, P., McCormick, M., McMaster, L., Chu, W., Swissler, T., Osborn, M., Russell, P., Oberbeck, V., Livingston, J., and Rosen, J.: SAGE II aerosol data validation based on retrieved aerosol model size distribution from SAGE II aerosol measurements, J. Geophys. Res., 94, 8381-8393, doi:10.1029/JD094iD06p08381, 1989.

Wang, Y., Logan, J. A., and Jacob, D. J.: Global simulation of tropospheric $\mathrm{O}_{3}-\mathrm{NO}_{x}$-hydrocarbon chemistry: 2. Model evaluation and global ozone budget, J. Geophys. Res., 103, 10727-10755, 1998.

Wang, Y., Zhang, Q. Q., He, K., Zhang, Q., and Chai, L.: Sulfatenitrate-ammonium aerosols over China: response to 2000-2015 emission changes of sulfur dioxide, nitrogen oxides, and ammonia, Atmos. Chem. Phys., 13, 2635-2652, doi:10.5194/acp-132635-2013, 2013.

Waters, J. W., Froidevaux, L., Harwood, R. S., Jarnot, R. F., Pickett, H. M., Read, W. G., Siegel, P. H., Cofield, R. E., Filipiak, M. J., and Flower, D.: The earth observing system microwave limb sounder (EOS MLS) on the Aura satellite, IEEE T. Geosci. Remote, 44, 1075-1092, 2006.

Weigel, R., Borrmann, S., Kazil, J., Minikin, A., Stohl, A., Wilson, J. C., Reeves, J. M., Kunkel, D., de Reus, M., Frey, W., Lovejoy, E. R., Volk, C. M., Viciani, S., D’Amato, F., Schiller, C., Peter, T., Schlager, H., Cairo, F., Law, K. S., Shur, G. N., Belyaev, G. V., and Curtius, J.: In situ observations of new particle formation in the tropical upper troposphere: the role of clouds and the nucleation mechanism, Atmos. Chem. Phys., 11, 9983-10010, doi:10.5194/acp-11-9983-2011, 2011.

Wesely, M.: Parameterization of surface resistances to gaseous dry deposition in regional-scale numerical models, Atmos. Environ., 23, 1293-1304, 1989.

Wu, L. T., Su, H., and Jiang, J. H.: Regional simulations of deep convection and biomass burning over South America: 2. Biomass burning aerosol effects on clouds and precipitation, J. Geophys. Res., 116, D17209, doi:10.1029/2011jd016106, 2011.

Wu, S., Mickley, L. J., Jacob, D. J., Logan, J. A., Yantosca, R. M., and Rind, D.: Why are there large differences between models in global budgets of tropospheric ozone?, J. Geophys. Res., 112, D05302, doi:10.1029/2006JD007801, 2007.

Wu, S., Mickley, L. J., Jacob, D. J., Rind, D., and Streets, D. G.: Effects of 2000-2050 changes in climate and emissions on global tropospheric ozone and the policy-relevant background surface ozone in the United States, J. Geophys. Res., 113, D18312, doi:10.1029/2007JD009639, 2008.

Xia, X., Zong, X., Cong, Z., Chen, H., Kang, S., and Wang, P.: Baseline continental aerosol over the central Tibetan plateau and a 
case study of aerosol transport from South Asia, Atmos. Environ., 45, 7370-7378, 2011.

Xiong, X., Houweling, S., Wei, J., Maddy, E., Sun, F., and Barnet, C.: Methane plume over south Asia during the monsoon season: satellite observation and model simulation, Atmos. Chem. Phys., 9, 783-794, doi:10.5194/acp-9-783-2009, 2009.

Yanai, M., Li, C., and Song, Z.: Seasonal heating of the Tibetan Plateau and its effects on the evolution of the Asian summer monsoon, J. Meteorol. Soc. Jpn., 70, 319-351, 1992.

Yao, X., Chan, C. K., Fang, M., Cadle, S., Chan, T., Mulawa, P., He, $\mathrm{K}$., and Ye, B.: The water-soluble ionic composition of $\mathrm{PM}_{2.5}$ in Shanghai and Beijing, China, Atmos. Environ., 36, 4223-4234, 2002.

Yin, Y., Chen, Q., Jin, L., Chen, B., Zhu, S., and Zhang, $\mathrm{X}$.: The effects of deep convection on the concentration and size distribution of aerosol particles within the upper troposphere: A case study, J. Geophys. Res., 117, D22202, doi:10.1029/2012JD017827, 2012.

Zeng, G., Pyle, J. A., and Young, P. J.: Impact of climate change on tropospheric ozone and its global budgets, Atmos. Chem. Phys., 8, 369-387, doi:10.5194/acp-8-369-2008, 2008.

Zhang, G. J. and McFarlane, N. A.: Sensitivity of climate simulations to the parameterization of cumulus convection in the Canadian Climate Centre general circulation model, Atmos.-Ocean, 33, 407-446, 1995.
Zhang, L., Liao, H., and Li, J.: Impacts of Asian summer monsoon on seasonal and interannual variations of aerosols over eastern China, J. Geophys. Res., 115, D00K05, doi:10.1029/2009JD012299, 2010.

Zhang, Q., Streets, D. G., Carmichael, G. R., He, K. B., Huo, H., Kannari, A., Klimont, Z., Park, I. S., Reddy, S., Fu, J. S., Chen, D., Duan, L., Lei, Y., Wang, L. T., and Yao, Z. L.: Asian emissions in 2006 for the NASA INTEX-B mission, Atmos. Chem. Phys., 9, 5131-5153, doi:10.5194/acp-9-5131-2009, 2009.

Zhang, X., Cao, J., Li, L., Arimoto, R., Cheng, Y., Huebert, B., and Wang, D.: Characterization of atmospheric aerosol over Xian in the south margin of the Loess Plateau, China, Atmos. Environ., 36, 4189-4199, 2002.

Zhang, Y., Dore, A., Ma, L., Liu, X., Ma, W., Cape, J., and Zhang, F.: Agricultural ammonia emissions inventory and spatial distribution in the North China Plain, Environ. Pollut., 158, 490-501, 2010.

Zhao, X., Turco, R. P., Kao, C. Y. J., and Elliott, S.: Aerosolinduced chemical perturbations of stratospheric ozone: Threedimensional simulations and analysis of mechanisms, J. Geophys. Res., 102, 3617-3637, doi:10.1029/96jd03406, 1997.

Zhu, J., Liao, H., and Li, J.: Increases in aerosol concentrations over eastern China due to the decadal-scale weakening of the East Asian summer monsoon, Geophys. Res. Lett., 39, L09809, doi:10.1029/2012GL051428, 2012. 